NBER WORKING PAPER SERIES

\title{
ORGANIZATIONAL CHANGE IN \\ FRENCH MANUFACTURING: \\ WHAT DO WE LEARN FROM FIRM \\ REPRESENTATIVES AND FROM \\ THEIR EMPLOYEES?
}

\author{
Nathalie Greenan \\ Jacques Mairesse \\ Working Paper 7285 \\ http://www.nber.org/papers/w7285
}

NATIONAL BUREAU OF ECONOMIC RESEARCH

1050 Massachusetts Avenue

Cambridge, MA 02138

August 1999

Prepared for the NBER conference on organizational change and performance improvement, 23 and 24 April 1999. We are grateful to David Author, Michel Gollac and the participants at the NBER conference on organizationalchange and performance improvement for their useful comments. The views expressed herein are those of the authors and not necessarily those of the National Bureau of Economic Research.

(C) 1999 by Nathalie Greenan and Jacques Mairesse. All rights reserved. Short sections of text, not to exceed 
two paragraphs, may be quoted without explicit permission provided that full credit, including $\odot$ notice, is given to the source.

Organizational Change in French Manufacturing :

What Do We Learn From Firm Representatives and From Their Employees?

Nathalie Greenan and Jacques Mairesse

NBER Working Paper No. 7285

August 1999

\section{ABSTRACT}

In this paper, we use a French matched employer-employee survey, the COI survey, conducted in 1997, to describe the general features of organizational change in manufacturing firms with more than 50 employees. In a first section, we explore the methodological issues associated with the building up of a statistical measure of organizational change, we describe the COI survey and we present the set of firm level and employee level variables that we have selected to investigate organizational change. In a second section, we present the results of two correspondence analysis, one conducted on a sample of 1462 firms from the COI survey and the other one conducted on the sample of 2049 blue collar workers affiliated to those firms.

On one hand, using the firm level section of the survey, we show that all types of new organizational practices are positively correlated with one another. On the other hand, at the blue collar level, three main dimensions discriminate between jobs: the intensity of involvement in information processing and decision, the intensity of constraints weighing on the content and rhythm of work and the orientation of information and production flows: either pushed by colleagues or pulled by the market. We also find that blue collars cannot develop a high level of involvement in information processing and decisions and have at the same time their work rhythm fixed by heavy technical constraints whereas high time pressure imposed on work rhythm by the market is positively correlated with such an involvement.

Finally, if we correlate firm level and worker level variables, we find that an increase in the use of "employee involvement " and "quality" practices by the firm is positively correlated both with a higher level of blue collars' involvement in information processing and decision and with a higher level of technical constraints, production flows being pushed by colleagues rather than pulled by the market.

The mapping of firm level responses stemming from our first correspondence analysis has been used to select 4 firms in different areas of the statistical universe and belonging to the "machine and equipment" sector. Post-survey interview carried out with executives from these firms and plant visit are used to check the quality of our statistical data and to better understand our descriptive results.

Nathalie Greenan

Centre d'Etudes de l'Emploi

Immeuble "Le Descartes I"

29 Promenade Michel Simon,

Noisy-Le-Grand

93166 Marne-La- Vallée Cedex.

greenan@cee.enpc.fr
Jacques Mairesse

INSEE-CREST

15 boulevard Gabriel Péri

92245 Malakoff Cedex

and NBER

mairesse@ensae.fr 


\section{Introduction}

Economists tell three different stories about organizational change and performance improvements. The first story comes from team theory, theories of hierarchy and theories of information processing. It is close to organizational theory and, more precisely, to theories of structural contingency. In this story, organizational change is a response to an external shock on the environment of the firm. The firm has to change the way she works internally in order to adapt to this new context. Observers have stressed different kinds of macro-shocks that have altered the global environment in which most of the firms operate. Globalization of economies and deregulation leads to higher uncertainty and complexity, while the diffusion of information and communication technologies and the increase in the general level of education in developed countries generate new technological and organizational opportunities. If this story is true, the firms that are not in a process of organizational change should be less efficient than others. Another version of this story focuses on the existence of complementarities in organizational design (Milgrom and Roberts, 1990). As a result, organizational features cannot be changed independently from one another and efficient firms are those that have been able to implement a whole cluster of changes. In other words all sets of organizational changes are not conducive to performance improvement. A "high performance organization" has selected the right (unique ?) set of new organizational devices.

The first story could be described as "functionalist". We will designate the second one as "constructivist". According to this story, firms change their strategy in order to gain a competitive edge on their rivals. In the last two decades, firms have developed new strategies based on high quality, short delivery times, new services complementing goods, rapid renewal of products. Either these new objectives are carried by market entrants that come in with new organizations or existing firms adapt their organization to be in the position to reach them. At the same time, new strategies disrupt the current rules of the game, upsetting markets and making transactions more uncertain and complex. Another consequence is that as they blur the frontier between price and quantities, new strategies make performance difficult to measure with traditional indicators like productivity.

The last story is radical. Over the past two decades, firms have invented new ways to spur higher effort from employees. These ways rely on new managerial practices that drag the market into internal organization of firms, dismantling the employment systems inherited from the past. These new arrangements have transferred adjustment costs on to smaller firms and workers. New organizational devices destroy good jobs and are more demanding on workers for less counterparts. Their diffusion has been backed up by the slow growth, the increased international competition and the development of financial markets. According to this story, organizational change should increase productivity and/or financial performances, to the detriment of workers' conditions of work and living.

According to these three stories, organizational change is correlated with performance improvements. However, in France, statistical studies on firm level data relating 
organizational change and productivity measures (Coutrot, 1996; Greenan, 1997b; Greenan and Guellec, 1998) show rather weak evidence of this relation. At the same time, labor force surveys indicate that between 1984 and 1993, greater pressure has been imposed on employees leading to deteriorated conditions of work (Cézard, Dussert et Gollac, 1992; Gollac and Volkoff, 1996). The increased strain imposed on workers has also been underlined by empirical studies based on data for the US (Cappelli and alii, 1997). But empirical research on productivity impacts of organizational change in the US leads to results that are more positive than in France ${ }^{1}$ (Ichniovsky, Shaw and Prennushi, 1997; Black et Lynch, 1997; Brynjolfsson and Hitt, 1997; Ashkenazy, 1998). Yet, either data sets are not directly comparable to the ones used in the French studies, or positive results are conditional (on the use of IT, on the presence of a union, on implementation characteristics etc.).

Even if the stories we examined tend to favor the thesis of a positive correlation between organizational change and performance, they give some hints about possible low measured productivity impacts. According to the first story, there may be some high adjustments costs to organizational changes, especially if changes are clustering. Thus there is a fixed cost to pay before gains appear. In addition, the clustering of organizational practices is a source of biases in estimations. However, productivity remains a good performance indicator if the production function is estimated jointly with a demand for organizational practices (Athey et Stern, 1998). If we trust the second story, some adjustment costs may also delay the arrival of performance improvements. But in this case, productivity is not always the best performance indicator. Performance indicators, like indicators of organizational change must be thought of in relation with the strategy of the firm.

Finally, if we focus on the last story, we have to be careful with indicators of organizational change stemming from the point of view of management. They may not be sufficient to discriminate among practices. The point of view of employees is complementarity because it gives better indications on working conditions and effort. Productivity should be a rather good performance indicator, but it is also important to look at financial performances. Measures of deteriorated working conditions could be interpreted as pieces of evidence for this third story, but they can also be interpreted as measures of adjustment costs in the other ones: work becomes more stressful because organizational changes are brutal in response to the clustering of practices, or because all the consequences of changes on the workforce have not been properly anticipated, for instance consequences on aged workers or on workers with low level of education.

At this stage of our work, we are not able to test one story against the other. More modestly, we are going to explore a French statistical survey, the COI survey, that allows to go a little deeper into the rationale of organizational change and complement it with field work. The

\footnotetext{
The same kind of difference in French/US empirical results on productivity impacts is obtained when IT indicators are used.
} 
COI survey is a matched employer / employee survey on organizational change and computerization that has been conducted in France at the end of 1997. As it is experimental, manufacturing is the only sector where a large and representative sample of firms and workers have been interviewed, because parts of the questionnaires had been already tested through preceding surveys. As a result, we limit our investigations to this sector.

The main purpose of this paper is to find out what are the best variables to address the organizational change and performance issue. We have been working in two steps. First we use a large set of variables to describe the anatomy of organizational change in French manufacturing through descriptive analysis. The resulting "mapping" of organizational changes is used to select four firms in different areas of the statistical universe. Second, we conducted post-survey interview in those firms, where we checked whether the statistical differences used for selecting them were discriminant. We also asked for more details about the sequence of changes and its underlying strategy.

In a first section we explain how we measure organizational change through variables built on the COI survey. Then we present the main results of our statistical analysis and illustrate them with our four case studies. In a conclusion we link what we observed in the field with our three stories about performance.

\section{A set of organizational change measures}

Organization, and organizational change is hard to measure. This has been widely acknowledged by structural contingency theory and its multiple attempts to gather statistical, information on a wide scale ${ }^{2}$. Moreover, we want to think of measures that do not need the presence of an expert in the field of organization to be implemented. Surveys we are interested in are either postal surveys were the respondent fills up a questionnaire on his own, or telephone or face to face survey conducted by the usual persons involved in government surveys. One clear cut solution is thus to design a set of questions that uses the vocabulary of managerial practices to interview some firm representatives about the changes implemented in their firm. In a first section, we are going to explore this solution and its limits, in a second section we will present the option chosen in the COI survey, and in the last section, we will go through the measures that we have chosen for the purpose of this empirical study.

\section{1-1 The new managerial tool-box}

Many observers have stressed their impression of an acceleration of technological change since the oil crisis, while growth was slowing down. It is one expression of the widely debated

\footnotetext{
${ }^{2}$ See Miller and Friesen, 1984 for example.
} 
productivity paradox. But as the technologies of information and communication were diffusing among developed countries, managerial concepts also flourished.

In France, at the beginning of the 1980's people that were not specialized in management had heard about quality circles and may be matrix organization. During the 1980's and 1990's, managerial knowledge spread in many directions. New theories were invented by management scholars and marketed rapidly through books and journals. Firms got into the habit of "auditing" while confronted with difficult strategic decisions, driving the growth of the consulting sector. At the same time, new words and acronyms came into the current language. As a matter of fact, words are a very important dimension of managerial innovations: like slogans, new managerial concepts are often expressed in a few words that can be easily memorized in order to influence attitudes and drive action.

These managerial words have a rather high obsolescence rate. In a way, managers became fashion victims. Like fashion nowadays, managerial practices are pervasive and international: the managerial tool box looks very much the same across countries and all the more so when firms are multinationals. It has also a mixed ethnic origin. American engineers have had a very strong influence on management practices in the western world during the first half of the $20^{\text {th }}$ century. In the second half, the principles laid down by these pioneers have been revisited and experimentation has been very active in countries like Japan or Sweden. The new managerial tool-box benefits from all these influences.

Nevertheless, although similar changes seem to take place in different countries, comparisons have to be cautious. Some practices are very much the same across countries and the vocabulary used to designate them is either the same or comes from literal translations from one language to the other, but this is not always true. In Appendix 1, we have listed a set of practices currently found in the Anglo-Saxon and French managerial literature and translated them from French to English. The influence of American management is strong in France as is witnessed by the use of "Reengineering" or "juste-à-temps" (literal translation of "just-intime"). However, some differences between France and the US must be stressed.

First, "employee involvement practices" is commonly used in the Anglo-Saxon literature like a generic expression designating organizational innovations of the past two decades. The proper translation in French would be "pratiques d'implication de la main d'œuvre". It is sometimes used in management books translated from the English to the French, but not on a wider scale. "Pratiques participatives" would be closer to the American use of "employee involvement practices". But its connotation is quite different. Instead of stressing a higher effort of employees, it underlines the sharing of information: "participatif" means that employees participate in decision making, they are consulted or at least informed when the firm is changing its strategy. Furthermore, the extensive use of this expression has its origin in a law taken in 1982 ("Loi Auroux") at the beginning of Mitterrand's mandate, that tried to encourage information sharing between employers and employees. 
Second, French firms seem to use extensively a set of practices that tend to increase formalization through the implementation of precisely defined procedures: registered quality systems like ISO or EAQF norms; methods that aim at analyzing the consequences of product or process choices on the customers utility, process hitches, equipment breakdowns or safety like value analysis, "analyse fonctionnelle" or "AMDEC"; formal in-house customer suppliers contacts between different departments in the firm. We do not mean here that these practices are not used by American firms, but that the managerial literature does not put the same emphasis on them between the two countries. For example, TQM seems more important in United States than quality certification when the latter is a big issue in France. Although connected with one another, these two practices have different implications.

Third English is much richer in describing the characteristics of jobs than French. Job rotation, multi-tasking and multi-skilling are three expressions that describe increased complexity of jobs. In French, one word only is used: "polyvalence". This could be so because jobs are thought of in reference of a "work post" with detailed characteristics more than in reference with competencies carried by the employee who fulfills the job (Maurice, Sellier and Silvestre, 1982).

Last, firms do not say that they downsize in France. Rather, journalists and executives talk of "restructuration" which is an euphemism. The persistence of high unemployment rates makes it unacceptable to display cutting jobs as an objective. It has to be announced like something that is inevitable, in order to secure the survival of the firm. As a result, it is seldom thought of as a choice.

In total, world wide diffusion of the new managerial tool-box allows to design questions using its vocabulary in order to build up measures of organizational change. However, this strategy has to be cautious. From one country to the other, firms may develop a specific use of the tool box, connected with local institutions. Furthermore, practices that often appear bunched together in the journalistic literature may not follow one unique direction of change. Depending on the practice, higher involvement, empowerment, higher formalization, cost reduction or flexibility are favored. Thus, we may guess that these practices do not necessarily go hand in hand with one another. For example, tight deadlines may interfere negatively with a thorough management of quality ${ }^{3}$. Increased formalization may limit empowerment: employee has full responsibility in a tight framework defined by precise procedures. Increased formalization may also be an indicator of restructuring and downsizing or of increased corporate control in ever growing multinational firms (it is used to issue measures of relative performances of the production units). At last, downsizing and reengineering may aim at increasing short term profit, an objective that may be in contradiction with the building up of innovative capabilities.

\footnotetext{
${ }^{3}$ See for example, the model of Keren and Levhari (1989), based on information processing theory.
} 
The COI survey that we are going to briefly describe in the next section tries to overcome these limits by associating a business survey on changes in organizational practices and a labor force survey.

\subsection{The specificity of the COI survey}

\section{Description of the survey}

The COI survey ("Changements Organisationnels et Informatisation") has been conducted at the end of 1997. It is a group of 3 business surveys matched with one labor force survey ${ }^{4}$. As a matter of fact, the French government surveys organization and technology use topics since the middle the 1980s'. Appendix 2 gives the background and some details about the surveys that preceded the COI survey. The business part of the COI survey in manufacturing is modeled after the 1993 SESSI survey on "organizational change in production" whereas the labor force questionnaire takes on the so called TOTTO survey, carried out in 1993 by the Ministry of labor (DARES). In our empirical work, we focused on the manufacturing sector where the survey benefited from high response rates both on the firm side $(88 \%)$ and on the workers side $(71 \%)$.

The business survey in manufacturing focuses on changes in the internal organization of the whole firm (not only on the production department). It has been postal. The firm response is given by a firm representative chosen by the headquarters of firm. In fact the statistical office of the Ministry of Industry is in contact with an interlocutor in all firms for the annual survey of manufacture. The COI questionnaire has been sent to this person with a letter saying that the headquarters, the human resources department, the production department and the IT department were concerned. The letter also informed the firm that some workers randomly selected were being interviewed, but of course it did not give their names. The last question of the survey is about the affiliation of all the persons that participated in building the firm's response.

Interviewed workers have been randomly sampled in the staff of interviewed firms from a file of government origin that gave the list of all the workers present in the firms on the $31^{\text {st }}$ of December 1996. Workers have been interviewed about one year later. Thus, they are

\footnotetext{
${ }^{4}$ One business survey covers manufacturing and food industries. The Ministry of industry (SESSI) conducted the survey in the former while the Ministry of Agriculture (SCEES) took care of the later, the two others are exploratory surveys in a branch of commerce (home depots type of stores) and in a branch of business services (accountants) carried out by INSEE (National Institute for Statistics and Economic Studies). The labor force survey has been conducted by the Ministry of labor (DARES). 8812 workers have been interviewed, belonging to 4025 firms with more than 50 employees in manufacturing and food industries and with more than 20 employees in the service branches. The conception of the business survey in manufacturing and of the labor force survey and the coordination of the 4 surveys has been directed by Nathalie Greenan at the Centre d'Etudes de l'Emploi.
} 
representative of workers with at least one year of seniority within interviewed firms. They are asked to describe their every day work in 1997. The labor force survey has been carried out by phone or face to face when the selected person could not be reached by phone. In both cases workers have been interviewed in the context of their leisure time. Each respondent has been asked if he or she was willing to meet a researcher later on and $30 \%$ accepted the principle of another interview.

So the main principle of the survey is to interview at the same time firm representatives and employees on organizational topics and technology use in order to measure at the same time the workers' point of view and the managerial point of view ${ }^{5}$. This cross questioning has many advantages.

\section{Advantages of the cross questioning of firm representative and workers}

Interviews of firm representative and of workers allow to measure the diffusion of the new managerial tool box in different ways. Firm representatives have a clear picture of strategy matters and understand the managerial vocabulary. If they have not just arrived in the firm, they know what kind of organizational devices are being adopted, why, and they also have their own feeling about obstacles and implementation difficulties. But their answers may be influenced about what they think a modern corporation is like and this may induce a bias towards a positive correlation between organizational devices if this picture is one of a firm with the latest managerial tools.

On the other hand, workers can describe precisely their every day work. While testing different questions on the two types of interlocutors, it appeared that firm representatives could answer more easily to questions on organizational change than to questions on the state of organization, while the reverse was true for workers. Of course, the formulation of the questions in the labor force survey must take into account the position of the interviewed person in the firm. Most of the workers that are not part of the managerial staff do not understand the vocabulary used in the business survey. Thus questions have to be factual and simple.

\footnotetext{
${ }^{5}$ The idea of the survey originated from a seminar on innovation and performance improvements organized by Dominique Foray and Jacques Mairesse in 1994-1995. A first description of the project was discussed collectively in a group and written up by Michel Gollac and Nathalie Greenan (Caby and alii in Foray and Mairesse, 1999). In the 1990's, in response to the labor market situation, the Ministry of Labor (DARES) became more and more interested in understanding how it related with firm practices. Furthermore, labor force surveys tended to suggest that an increasing share of workers felt high pressure at work. On the other hand, the Ministry of industry (SESSI) wanted to improve knowledge on the skill bias of technological change. As a result both statistical services adopted the project that was to become the COI survey. INSEE got involved because she was interested in the new methodology of the survey and was sub-contracted by DARES to conduct the labor force survey.
} 
Moreover, numerous organization studies have pointed out the discrepancy between formal organization and current practices. Firm representatives generally describe formal organization, whereas workers can be asked about what they really do and how they adapt assignments to the context of their work. Topics like empowerment, worker involvement and greater autonomy on the shop-floor cannot only be investigated through what management knows about it. It is even more true for considerations about intensification of effort, stress or all type of adjustment costs caused by organizational change. As far as performance is concerned, it also appears that the key issue is in the interaction between the efforts spent by individual workers and the structure of the organization (Harris, 1994). The interview of both firm representatives and workers allows to go one step further in the understanding and description of these linkages.

\section{Methodological issues}

As far as the statistical approach is concerned, a matched employer / employee survey raises methodological issues. The first one is to decide how many workers to interview per firm. It seems difficult to build up serious measures without a large sample of workers within each firm. But this is costly, especially when compared with traditional business survey where the answer of "the firm" is most of the time the answer given by one person allowed to talk in the name of the organization.

The COI survey took another option: 2 workers per firm have been interviewed in firms with less than 500 employees, 3 workers in bigger firms. This choice has been backed up by previous empirical work using the TOTTO survey to measure the impact of computer use on firm productivity (Greenan, Mairesse, 1996 ; Mairesse and Greenan, 1998). It showed that although variables measured on the basis of answers of a small number of employees per firm are subject to important sampling errors, they can be usefully included in a model specified at the firm level. Biases arising from the sampling errors in the employee-based variables can be assessed, as long as there is a large enough sample of firms with 2 or more employees selected at random. Moreover, results about the significance of coefficients are robust.

Another methodological problem is related to the fact that the content of work depends strongly on the job and on the position occupied by the worker in the organization. Unlike the indicator on computer use, answers of all types of workers on organization cannot be treated symmetrically. As we have decided to investigate manufacturing industry, we have also chosen to focus on the answers of the largest category of employees: blue-collar workers. With their one year of seniority, they belong the "core" of the shop-floor workforce. The sample of the survey includes 2049 blue collars working in 1462 manufacturing firms with more than 50 employees. 


\subsection{Two sets of organizational change measures}

Most of the time, empirical studies in economics concentrate on a small number of quantitative variables: IT investment, $R \& D$ expenditures etc. The difficulty with organization is that it cannot be summarized with one quantitative variable. Rather, a large set of qualitative variables are potential candidates. Most econometric studies relating organizational changes and performance have focused on a small number of variables in this set: TQM, job rotation, self-managed teams, number of hierarchical layers.

If we measure organizational change through a statistical survey, it does not make sense to focus on one specific new organizational practice whereas this can be a suitable strategy in field work. On a large sample of firms, all types of firms coexist and some of them have adopted multiple new organizational devices. Thus, we must take into account a broad range of organizational practices because they may all interfere with performance improvements. They are measured from answers given by firm representatives speaking in the name of the organization and by employees describing their everyday work. Choices are in the continuity of preceding work based on the TOTTO survey (Greenan and Guellec, 1998) and on the survey on "organizational change in production" (Greenan, 1997a and 1997b).

\section{The business section of the COI survey}

In the business survey questionnaire, we selected 4 sets of questions (84 "primary" questions in total), that deal with new organizational devices, with work in groups or teams, with the allocation of tasks on the shopfloor and with the number of hierarchical layers. All these questions are reported in box 1 with percentages for each type of answers from the whole sample of interviewed firms with more than 50 employees.

\section{[insert box 1]}

The variables stemming from these questions are of a qualitative type, either dichotomous or with three ordered items. After analyzing their distribution, we decided to build up synthetic variables in order to deal with a smaller number of them while loosing little information. Most of the questions are expressed in terms of the existence of a list of practices in 1997 and either on their existence in 1994 or on the change in their scope within the firm (measured by the share of concerned workers) between 1994 or 1997. It is then possible to analyze separately practices in 1997 and their evolution within firms during 3 years (1994-1997). Nevertheless, statistical analysis shows a strong path dependency during such a short time period. Firms that abandon or reduce the scope of "high performance" practices or firms that jump from one extreme to the other are very rare. In other words, firms have about the same relative profile compared with others, on the basis of information on their situation in 1997 and on the basis of information on the evolution of this situation. In order to grasp some deeper effects, we chose to process at the same time the two types of information. 
We explain, under each set of questions in box 1 how the corresponding synthetic variables are constructed. We obtain 16 variables with a varying number of items, summing up to 56 . They are listed in table 1 where we keep the same variables names as in box 1 . In table 1 , we break the order of the questionnaire and group the variables into two main categories: devices that shape the information system of the firm and devices that shape its production system.

\section{$\underline{\text { Information system }}$}

The information system of the firm is first described through its general structure. We group 4 variables have an influence on how corporate decisions are taken: organization in profit centers (OPC), formal in house customer / supplier contracts (CSC), number of hierarchical layers (HL) and change in this number (EVHL). For instance, more profit centers $(11 \%$ of firms) indicates a decentralization of decision in the sense used by traditional theories of hierarchy. This is also the case for an extension in the use of formal in-house customer / supplier contracts $(13 \%)$ or for a reduction in the number of hierarchical layers $(18 \%)$.

\section{[Insert table 1]}

Variables measuring involvement of employees in information and processing decision describe another type of change in the information system of the firm. It indicates how operational decisions are decentralized towards direct producers. We use three types of variables: the percentage of production and non production workers participating in problem solving groups (PSG) and project groups (PRG), the existence and evolution in use of $5 \mathrm{~S}$ method or total productive maintenance (TPM) and the way currents tasks are shared on the shop-floor between the hierarchy (HIE), production workers (PW), and specialists (SPE).

Box 1 shows that involvement in "information processing" groups or teams is measured with three different intensity items giving the percentage of concerned employees in $1997(0-10 \%$, $10 \%-50 \%$, more than $50 \%$ ). Manufacturing firms with more than $50 \%$ of workers involved in problem solving groups (respectively project groups) are rare: $4 \%$ (respectively $2 \%$ ) of them declare such a proportion for production workers and 6\% (respectively 6\%) for non production workers. Thus, we grouped together the medium and high item. The resulting variable measures the existence of such groups on a non negligible scale. Moreover, the correlation between the answers given for the two types of workers is strong. This is why we built a synthetic variable crossing the two dichotomous variables.

Total productive maintenance and $5 \mathrm{~S}$ method are also connected with an involvement of workers in information gathering. $5 \mathrm{~S}$ method originated in Japan. Like total productive maintenance, it aims at motivating workers in collecting information about all the small hitches into the production process. $5 \mathrm{~S}$ method insists on tidiness and order in the working environment so that problems are more easily detected. Only a small number of firms had adopted one of these methods in $1997(17 \%)$. 
The division of work between production workers, hierarchy and specialist workers is seized with a set of 60 "primary" questions (see box 1). Each question is about a task that is currently achieved on the shop floor. These tasks are not direct production ones, they have to do with the preparation of work (sharing work, setting machines), information processing (controlling quality, contributing to performance improvement) and with decision (setting machines, stopping and starting production in case of an hitch). Questions are about how the responsibility for each task is shared between the production worker, the hierarchy and specialists in 1994 and in 1997. The information embedded in this series of questions is very rich. We decided to make up three variables out of it, giving at the same time a measure of the size of the responsibility sphere of each worker category and of its evolution between 1994 and 1997. Each variable takes 4 items.

Two of them describe situations where responsibilities have remained stable between 1994 and 1997, with a distinction in the number of tasks each category is responsible for. Chosen bounds are the median number of tasks in 1997 computed on the whole sample. Hierarchy is in general responsible for more tasks (in the listed range) than production workers or specialists and her prerogatives are more stable: her responsibilities remained unchanged in $84 \%$ of firms whereas this figure amount $77 \%$ for specialists and $71 \%$ for production workers.

The 2 other items describe situations of changing responsibilities: some tasks appear, others disappear. Here again, items were chosen for each category according to the distribution of the variable. In the case of production workers for example, it is only in a very small number of firms $(3 \%)$ that some tasks disappear. Thus, when the number or disappearing tasks was greater or equal to the number of appearing tasks, the situation has been considered as stable. In the opposite situation, firms have been classified as increasing the responsibilities of production workers. We distinguish firms where production workers gained 1 to 3 tasks $(18 \%)$ and firms where they gained 4 tasks or more $(11 \%)$. Of course, these gains are strongly correlated with the numbers of tasks production workers are in charge of in 1997. For the hierarchy and specialists, we built two categories according to whether the number of appearing tasks was greater than the number of disappearing ones ("increase" category and "decrease" in the opposite case). When the tasks of the hierarchy change, it is more often a reduction in the numbers of tasks ( $12 \%$ of firms against $4 \%$ for "increase"). As for the specialist, his number of tasks increases as often as it decreases (12\% and $11 \%)$.

\section{$\underline{\text { Production system }}$}

The remaining variables describe practices that change the production system of the firm. A first question on autonomous work teams (AWT) has been transformed in the same way as questions on "information processing groups". This variable indicates if the primary unit of work in production is the individual or a collective entity.

Two other groups of questions identifies practices that induce increased horizontal complementarities between workers or units, either because of tight time schedule and 
production flows ( 2 variables) or because of high quality standards ( 3 variables). Each of them implies the formulation and implementation of a new procedure to be followed by workers: just in time delivery (DJIT) or just in time production (PJIT) for the former, ISO norms or EAQF (ISO), total quality management (TQM) and value analysis of AMDEC method (AMD) for the latter. These synthetic variables take 3 items: the firm is not using the device in 1997, the firm is using it but it has not been extended in terms of concerned workers since 1994 , the firm is using it and has increased the number of workers concerned.

\section{The labor force section of the COI survey}

Questions asked to workers are less "technical" than those asked to firm representatives. As we already said, the vocabulary describing the managerial tool box is not understood by all types of workers and the option taken COI survey, like the TOTTO one, is to work with one unique questionnaire. Questions are about the way everyday work takes place within the firm.

We kept all the questions that were connected with the selected business survey variables. For example, blue collar workers are asked they have to meet precise quantifies quality standards like wastage rates or measurable characteristics of the product. We guess that the answer to this question should be connected with the answer of the firm representative about quality registration systems or total quality management practices. Box 2 gives the 41 questions selected from the labor force survey and the percentages of positive answers from the whole sample of interviewed blue collars.

\section{[Insert box 2]}

Here again, like with the business survey, we decided to make up a smaller number of synthetic variables. Most of the questions lead to an answer of a "yes or no" type. By summing up the number of positives answers on precise topics, we are able to build up variables that give an idea of the intensity of some aspects of the effort spent by blue collars. For example, 4 questions indicate whether the worker communicates with his colleagues on different purposes in the course of his work. With the number of positive answers to these questions, we build up a variable that proxies the intensity of horizontal communication. In box 2, questions that are grouped together under one heading are used to make up one synthetic variable which name and number of items is given in between brackets (14 variables in total). Appendix 3 explains precisely how each synthetic variables is built from the "primary" variables. In table 1, synthetic variables are grouped together according to the categories we used for presenting the variables from the business section of the COI survey.

\section{$\underline{\text { Information system }}$}

The decentralization of the hierarchical structure of the firm is difficult to address through the interview of blue collar workers. Thus, there is no question to corroborate the answers given by firm representatives. 
Involvement in information processing and decision is seized through a group of 8 variables. A first set of 5 variables give some indications on communication: vertical and horizontal communication (CVER and CHOR), communication with other services (CWITH), communication with outside the firm (CBETW) and contact with the customer (CUS). On the shop floor, a majority of blue collar workers communicate with their boss and their colleagues in one way or in another. Communication with other departments in the firm is rarer: nearly half of blue collar workers attached to the core of firms' workforce do not discuss, nor are helped, nor exchange indications with other departments. Finally, $81 \%$ of blue collar workers are not involved in information exchanges about their work with persons from outside the firm and $87 \%$ are never in direct contact with the customer. This leaves $19 \%$ of them involved in such exchanges, $6 \%$ of them doing it for multiple purposes and $2 \%$ being in constant contact with the customer.

The number of meeting per year attended by blue-collar workers (MEET) measures institutionalized or formal ways to communicate. In a meeting, communication takes place between a group of people whereas the other forms of communication that we mentioned are more bilateral. On the whole, $43 \%$ of blue collar workers never participate into meetings in the context of their work and $28 \%$ attend one or more meetings a year.

The synthetic variable on the scope of initiative (SCOPI) sums up different types of hierarchical constraints. The workers are considered to have no scope of initiative when they cannot modify the nature or quantity of work they have to carry out, or the way they proceed. Supervisors give precise instructions about how to do the work, they follow instructions to the letter and are frequently checked. When unforeseen contingencies occur, they call on other people to fix the problem. About $19 \%$ of interviewed workers have to comply with 3 or more of these hierarchical constraints. On the other extreme, $35 \%$ of blue collar workers have some scope to adapt assignments to their need or to define themselves the content of their work. The remaining $46 \%$ experiment moderate hierarchical constraint: they have no scope for changing things, but direct supervision is not very strong.

The last variable measuring involvement of blue collar workers in information processing activities comes from a question on proposition for process improvement (PPIM). 62\% of blue collar workers declare such propositions, which is rather high.

\section{Production system}

The rest of the questions are more directly linked with what the worker does in the course of direct production. Does he work in group or collectively (GROU)? Is his work rhythm constrained by quantitative norms or deadlines (RXX) or by horizontal linkages with his colleagues or with the customer (RCXXX) ? Is his work rhythm constrained by machines or by the design of the work process (RTEC)? And has he to respect some precise quality norm (QUAL) or to participate in product testing (TEST)? We consider that all these variable measure some sources of complementarities between workers in the work done: due to the 
collective nature of work, due to time schedule and production flows, due to equipment or to the production process itself and due to quality standards.

About half of interviewed blue collar workers never work within a group or collectively, but a little more than one fourth do it all the time. Very tight time constraints are declared by about one third of blue collar workers: in this case work rhythm is defined by an external demand needing an immediate response. This complements information on contacts with customers. If only $13 \%$ of blue collar workers have direct contact with customers, they impose tight work rhythm on $31 \%$ of them. Another $45 \%$ of direct producers have production norms or deadlines to meet between 1 hour and one day. The remaining $25 \%$ work with slack deadlines.

The identity of the person who influences the production flow gives another information. It can either be a colleague or the customer. We have already measured whether customer was imposing a tight time constraint. But external demand may not always require immediate response. We find that $36 \%$ of interviewed workers do not have their work rhythm imposed by either customers or colleagues. On the opposite side of the scale, $19 \%$ refer both to the influence of customers and colleagues on their work rhythm. The remaining half is shared equally between situations where only colleagues are a source of pressure and situations where only customers are so. We can derive a third information on the influence of customers on production work from this variable: it concerns $42 \%$ of blue collars if we take into account both tight and slack pressures on work rhythm.

Technology itself is another, more traditional, source of horizontal pressure on work rhythm. The conveyor belt is the best example. We built a synthetic indicator on technological constraints summing up a variable on rhythm imposed by automatic moving of a product or a part, a variable of rhythm imposed by automatic pace of a machine and a variable on repetitive work. $45 \%$ of blue collars are not concerned by those constraints and $31 \%$ are concerned by 2 or all of them. Thus, more traditional ways of constraining direct production work are not out of date in manufacturing. Contrary to questions on the hierarchical structure, information on technical constraints is only measured at the worker level. But in this case, our lack of data is not connected with a measurability problem. The information is not available in the business section of the COI survey because a preceding SESSI survey focused on manufacturing technology ${ }^{6}$.

Finally, two variables indicate whether workers have to be attentive to the quality of production. $47 \%$ of direct producers have to meet precise and quantified quality standards and $52 \%$ participates in product testing.

\footnotetext{
${ }^{6}$ However, we have not been able to match the two surveys yet.
} 


\section{What did we learn about the survey in field work}

We used the survey to select some firms that we visited. Our first purpose was to check the quality of the data gathered through our statistical survey. Some firm and worker interviews had already been carried out in the conception phase of the survey, but they were strongly oriented around the intelligibility, wording and relevance of the questions. In conducting postinterviews, we wanted to go through the given answers asking for more details on what the firm was effectively doing. Apart from these questions around the survey, we focused our new interviews on the rationale of organization: when had the new practices been implemented, what was the strategy and the constraints that weighed on the choices? How were the practices connected with one another and with technological choices? We will come back on those aspects in another section.

We decided to focus on one industrial sector in order to limit the range of variation in variables other than organizational like technology or market. We wanted a sector opened on the global economy and innovative without being too prone to management fashion. We chose the "machines and equipment sector". It has experienced some restructuring during the 1994-1997 period, firms belonging to this sector often work in small batches and their main customers are other firms. In our sample, 60 firms and 86 blue collar workers belonged to this sector. We visited four of them noted respectively $A, B, C$ and $D$ in the following. We met either the head of the company or top executives responsible for production, organization or information technologies. In firm B, we conducted 3 interviews ${ }^{7}$. We will explain, in the next section how these firms have been selected within their sector.

We were pleased to find out that the business survey questionnaire had been filled up carefully in the four firms we visited. Respondents had all tried their best to answer to the questions. Imprecision did not come from their unwillingness to fill up a form from government origin, but from their lack of knowledge about some of the topics. As a matter of fact, SESSI maintains some courteous and trustful relations with firms through a network of people responsible for specific branches. It wasn't too difficult to obtain an appointment once we had sent a letter with some documentation about the COI survey and the response of the firm. In firm A and B, we found some errors in the part of the questionnaire about IT use. They were due either to an interpretation error (A), or to the fact that the respondent was about to retire and not very interested in new technologies (B). In firm B, that same person had ticked JIT delivery system and JIT production system, although we verified with the production manager that only deliveries were just in time. The distinction between the two types of system was too fine to be seized by the respondent who really thought that the two systems where used. More generally, it seems that the answers given by "structure" executives about the organization of direct production are more imprecise. However, new management

\footnotetext{
${ }^{7}$ In some further research, we will try and meet the production manager and a manager involved in the "structure" in each firm, and we will also contact one blue collar worker.
} 
tools that reinforce the communication links between the production sphere and the structure, and new integrated manufacturing software tend to improve the knowledge of executives.

Finally, we were surprised about what size meant in our field work. We had selected two small firm (A, 42 employees, C, 116 employees), one medium sized one (B, 320 employees) and one big firm (D, 1265 employees). However, we did not find any small firm in the field. First, all four firms belonged to a group, of French nationality for A and C, American for B and German for C. For A, it appeared that the real firm was the group, connecting three productive units summing up to 150 employees. $\mathrm{C}$ had three subsidiaries in France and commercial antennas abroad, this broader entity grouping 376 employees. She was owned by a holding company and had some strong connections with other French firms, this group representing about a 1000 employees. The structure of $\mathrm{B}$ and $\mathrm{C}$ was less ambiguous, at least at the level of France, for $\mathrm{C}$ was involved in a European group where some firms shared their product range while others were competitors on the same markets. We are going to see that these broader structures have a lot to do in the choices of internal organization, at least for A, $\mathrm{C}$ and $\mathrm{D}$.

\section{Statistical anatomy of organizational change in French manufacturing}

In this section, we are going to present the results of two correspondence analysis, one performed with the business survey variables and the other with the variables built on the answers given by blue collar workers. This statistical analysis is descriptive. Our aim is to find the best way to measure organizational change and to understand how the effort spent by blue collar workers is altered by organizational change. Of course, in the back of our mind, we have the idea of using these measures in some performance regressions.

Why do we choose correspondence analysis to describe organizational change? As we have already mentioned it, organizational change is a multi faceted shock on the information and production systems of firms. Thus, it is described by a large number of qualitative variables. Correspondence analysis is a suitable tool in this case. In France, it is often used in quantitative sociological research (Kramarz, 1986; Gollac, 1989) and economists sometimes recourse to it to describe firm behavior (Salais, 1992, Greenan 1997a, Greenan and Guellec 1998). This tool may show that the heart of information is embedded in a small number of variables highly correlated with all the others. In this case, it helps choosing these variables. Otherwise, it can be used to build up synthetic indexes that are particularly helpful when the variables of interest are latent, indirectly measurable through a large number of qualitative variables.

We are going to present our correspondence analysis both with figures and with correlation tables for the 5 items that contribute the most to the inertia of the axis. On figures, all items that have a contribution over the average are displayed, as well as items with contribution below average but that are significantly correlated with the axis. We also display the 
coordinates of firms (stars) and workers (faces) from the sector we chose for field work. The shape of the cloud of points for this sector is very much alike the shape for the whole sample.

\subsection{In the words of firm representatives, organizational changes cluster}

How do organizational practices and devices are arranged and evolve together within firms? We conducted a first correspondence analysis using information from the business section of COI on our sample of 1462 firms. Figure 1 gives the mapping originating from the crossing of the first and second axis of the correspondence analysis. It is complemented by table 2 that gives the correlation coefficients between the five variables that contribute the most to the inertia of each axis.

\section{[Insert figure 1 and table 2]}

Clearly, practices under examination cluster. The figure is organized around three different groups of items that are very close to one another: firms with no new organizational practices, firms with a stable use of them between 1993 and 1997 and firms that have either adopted them for the first time or that have extended their use. This indicates that all types of practices go hand in hand with one another and they tend to evolve at the same rhythm once they have been adopted. Although the COI survey is much richer than the survey on "organizational change in production", the result on the clustering of practices was already observed in 1993 (Greenan, 1997a). What we find here is in line with the description of the path to "excellency" that is described in management best sellers. It does not corroborate our feeling that that some of the practices may be in contradiction with one another. This result is the basis for the following proposition:

Proposition 1: All types of new organizational practices are positively correlated with one another.

More precisely, the first axis of the correspondence analysis represents $13 \%$ of total inertia. It opposes the "no" firms with the firms with an increasing use of new organizational practices. If we look more closely at the contribution of the different items to the inertia of the axis we find that the items with the strongest contribution to the negative part of the axis are the ones that measure no employee involvement in intellectual tasks and no implementation of practices oriented towards a thorough management of quality.

The third group of firms is clustering around the second axis representing $7 \%$ of total inertia. They produce and/or deliver their goods just in time, they have a decentralized hierarchical structure and they use procedures to guaranty high quality standards. But contrary to the second group of firms, they have not developed these practices between 1994 and 1997. Firms with negative coordinates on this axis have extended just-in-time practices and increased the decentralization of their structure. 
Thus, in an indirect way, our first axis is oriented by employee involvement and quality practices while the second axis is oriented by JIT and practices favoring the development of a kind of pseudo-market within the firm. The first ones are more often expanding while the second one are more stable.

This first correspondence analysis tends to show that the main variables are the number of organizational devices characterized by a stable and increasing use. Within devices, a distinction could also be made between "employee involvement" and "quality" devices on one hand, "just-in-time" and "pseudo market" devices on the other hand.

For our field work, we selected firms that were lined up along the first axis. This can be seen on figure 1: firm $\mathrm{A}$ has a negative coordinate on axis 1, then comes firm $\mathrm{B}$ with an intermediate position on the positive portion of axis 1 , firm $C$ and firm $D$ that are further up the axis. All 4 firms make different products, so they do not compete on the same market. Firm A makes prototypes of moulds for the automobile industry, firm B produces thermostats for car engines, heating systems and bathroom installations, firm $\mathrm{C}$ manufactures pumps to spray paint or varnish on cars, airplanes, furniture etc. and firm D is specialized in storehouse and handling equipment. We chose the position on axis 1 as a selection criteria because we felt that it opposed the most dynamic firms in terms of organizational change with the most inert own.

As a matter of fact, this feeling was comforted in the field. We accepted the ranking of firms in terms of intensity of organizational change once we completed our visits. Furthermore, it appeared that the position on the axis was a good predictor of performance. But not so for the reasons that we thought in the beginning.

When we contacted firm A, we learned that it had gone bankrupt in 1997 and that it had been bought over. We managed to organize an interview with the previous owner who had filled up the COI questionnaire. Firm A was very dependent on one car manufacturer that decided to internalize part of its development activity in a new technology center near Paris. She anticipated that her activity would not drop down immediately because the change in location would take some time. This was confirmed by the car manufacturer, but what happened in the end was a brutal cut in orders.

Firm B looked quite healthy in our first visit, but when we returned, we felt that its position was fragile: it had squeezed its margin under the pressure of car manufacturers in the recent years and was facing some challenges to secure its survival. Internal impediment, lying in labor relations and culture made organizational change difficult at a moment when it was needed. We cannot say though that firm B had not been successful in raising its productivity. It did so partly through organizational change. But if we measure productivity in value rather than volume (which is always the case on micro-data) this gains are invisible because B had to lower its price ( $4 \%$ in the last year). 
Firm C had gone through some heavy financial difficulties in 1992-1994 and was finally sold in 1995 to another firm, also specialized in pumps but used in agriculture rather than in manufacturing. During the six month that followed its take over, firm $\mathrm{C}$ implemented heavy organizational change as its production and commercial activities were restructured. In 1997 when the COI survey was conducted, the organization was brand new and the firm had growing benefits again.

Finally, firm D, the biggest we visited, had been hit by the 1993 downturn. In 1995, it changed the location of its headquarters and its strategy: product demand was to cyclical to be trusted, firm $\mathrm{C}$ decided to expand its offer of services in order to smooth demand. Its activity kept growing and between 1994 and 1997, it was able to expand its workforce, making it easier to shift from and engineer type of culture focused on the product towards a culture favoring the relation with the customer. In 1990, the production site had also changed its location and new organizational practices had been implemented throughout the $90 \mathrm{~s}$. We met the organization and IT manager, responsible for a team 18 persons, 3 of them being specialized in "organization" matters. In fact firm D tries to motivate transversal projects involving her headquarters (300 employees), production site (500 employees) and commercial network (500 employees) and the organization staff is there to do the follow up and give advice.

\subsection{Blue collars: Employee involvement, constraints, customers and colleagues}

The sample of blue collar workers affiliated with the 1462 manufacturing firms used in the firm level correspondence analysis is composed if 2049 respondents. Variables built on the answers given by blue collar workers are less correlated with one another than firm level variables: to reach a proportion close to $20 \%$ of total inertia, 3 axis have to be considered in the worker level analysis, whereas 2 where sufficient in the firm level analysis. This happens even though some of the respondents belong to the same firm. If organizational practices cluster, profiles of blue collar jobs are quite varied. Mappings originating from the crossing of axis 1 and 2 and 2 and 3 are respectively displayed in figures 2 and 3. Table 3 gives the correlation coefficients between the five variables that contribute the most to the inertia of each of the 3 axis.

Vertical, horizontal, within firm, between firm and group communication come together on the first axis. Blue collar workers who communicate a lot about work with their colleagues participate in a larger communication network involving other persons in the firm and sometimes persons from outside the firm like customers. On the opposite, blue collar workers who are not involved in horizontal communication experiment very poor on the job communication.

\section{[Insert figure 2]}


Two other variables are correlated with communication: scope of initiative and proposition for process improvements. Workers with low intensity of communication experiment high hierarchical constraints whereas numerous information exchanges favor some scope of initiative. This does not imply that horizontal and vertical communication are substitutes: workers with more initiative also communicate more intensively with their boss. Besides, they are more prone to proposing process improvements. Of course, these type of activities are unknown to workers under tight hierarchical supervision. As a matter of fact, nearly all the variables grouped together under the heading "involvement of employees in information processing and decision" in our table 1 contribute to the construction of the first axis. This leads to our second proposition:

Proposition 2: The intensity of involvement in information processing and decision is a discriminatory feature of work organization.

Communication and low supervision does not mean no constraints on work. The second axis summarizes the influence of constraints other than hierarchical on the content of work. Like different kinds of communication, high technical constraints, quality norms and permanent production work within a group are correlated with one another. Vice versa, some blue collar workers do not experiment any of those constraints nor tight deadlines. This leads to our third proposition.

Proposition 3 : The second prominent characteristic of work organization is the intensity of technical constraints positively associated with quality standards and negatively correlated with no time constraints.

The banana shaped size of the cloud of points in figure 1 shows however that when involvement in intellectual tasks is high, the intensity of technical constraints is low. This can be checked in table 3, through the crossing of variables from the first and from the second axis. No technical constraints is positively correlated with a high scope of initiative and a high level of communication with other departments the firm. And strong technical constraints are negatively correlated with the variables of the first axis denoting a high level of involvement in intellectual tasks. This calls on to our forth proposition.

Proposition 4: Workers cannot develop a high involvement in information processing and decision and have at the same time their work rhythm fixed by heavy technical constraints.

\section{[Insert table 3]}

These results are in line with the ones obtained in a similar analysis using the 1987 TOTTO survey (Greenan and Guellec, 1998). Intensity of communication and intensity of constraints appeared to be two strong dimensions structuring blue collar jobs. However hierarchical constraints were correlated with both axis whereas here, they are clearly isolated from the 
other types of constraints. This can be interpreted as a piece of evidence showing that constraints tend to shift in time with the diffusion of organizational changes.

The third axis separates jobs that are "pushed" or influenced by colleagues from jobs that are "pulled" or close to the market. On one side, workers are in contact with the customer or have their work rhythm constrained by them within very tight deadlines, on the other one workers communicate with colleagues or have their work rhythm influenced by immediate dependence on them in the work done. Our fifth proposition focuses on this result.

Proposition 5: Whether production and information flows are pushed by colleagues or pulled by the customer is a third discriminatory feature of work organization.

\section{[Insert figure 3]}

When production flows are pushed by colleagues and technical constraints are high, then colleagues impose a time constraint on work. If, on the contrary, technical constraints are low, time constraints are also weak and information exchanges are dense between colleagues. The same kind of association is observed with the influence of the market. When production flows are pulled by the market and technical constraints are high, then the customer imposes time pressure on production flows. On the opposite, with low technical constraints the proximity of the market does not mean increased time pressure for the worker, but rather information exchanges and direct contact with the customer.

The mapping of figure 3 determines four different types of working environment. Two of them have already been described with other surveys (Kramarz, 1986; Gollac 1989): the "industrial" environment and the "craft" environment. They are found in the north west and south east parts of figure 3 .

An industrial type of environment has strong technical constraints and quantitative norms. Here we find it enriched with quality standards. A craft environment has low technical constraints and time pressure, production work is more isolated than collective and direct contacts with the customer are frequent to define the characteristics of the products. None of the firms that we have visited are clearly of an "industrial" type in the words of their blue collars. Firm $\mathrm{C}$ is the closest to this king of work environment, but it is at the frontier of it. In fact, the interviewed worker is a storekeeper who prepares parts for shopfloor production work. This is why his work rhythm is not determined by technical constraints and his communication network is large. But he makes propositions for process improvement and has to follow some quality norms.

Firm A is classified in this analysis as a "craft" firm and it was verified in the field. Firm A makes prototypes of body moulds for a car manufacturer. Thus products are made upon orders and manufactured only once. Worekrs in firm A are highly skilled. They are recruited with a diploma equivalent to two years of study after high school. On average, they earned $50 \%$ 
more than employees in the three other firms whose earnings were close in 1997. The COI respondent in firm $A$ is a highly skilled worker who participates in the production of prototypes and controls shapes and dimensions using a personal computer. He seems to communicate more with the customer, who influences his work rhythm, than with his colleagues or other persons if the firm.

The two others types of working environment are less easily identifiable. In the south west part of the mapping we find workers that experiment low technical constraints, high scope of initiative and high horizontal communication. We may think of an industrial type of working environment with highly skilled workers. The interviewed blue collars in firm D is in between this "industrial" situation and the "craft" situation: he has some close connection to the customer, but he is also part of an industrial type of organization where links with colleagues are important. In fact, the examination of the questionnaire filled up by this worker had made us thought that services were important in firm D. Specialized in electromechanics, this employee works within a small maintenance team that he manages at the customer's place. The two other employees interviewed in this firm are technicians. This is why they are not in our sample for this study. However, one of them manages storehouses and the other does after sale services. The two of them have some direct contact with customers and have deadlines imposed by external demand needing an immediate response.

In the north east part of the mapping, technical constraints are high and the market puts high time pressure on the work. The two interviewed blue collars from firm B are precisely located in this area of the mapping. They have low skills and work as direct producers. Firm B has the highest capital intensity compared with the three other firms we visited. Some of the machines are entirely automatic, but others need manual operations and some of them are located in refrigerated premises so that the wax that is used in the thermostat is at the right temperature. One of the worker uses an entirely automatic machine and the other a semi automatic one. Both workers are never in direct contact with the customer, but their work rhythm is fixed by external demand that always require an immediate response. They also have to respect deadlines to meet in a day or an hour and their work consists in repeating the same series of operations. In fact, firm B is on three different markets: thermostat for car engines, spare parts and thermostat for heating system and bathroom installation. The first market is the more demanding: firm $\mathrm{A}$ is dominated by the car manufacturers she works for, and it is their influence that has entered the firm to a stage where they are able to pull the work rhythm of blue collars.

Table 3 also gives some information on correlations between variables from axis 1 and $3^{8}$. It is interesting to check the relation between high involvement in intellectual tasks and tight time

\footnotetext{
${ }^{8}$ The crossing between the items of the first and the third axis may suggest that high involvement is positively correlated with production flows pulled by the customer. However, this conclusion is wrong and due to our selection of variables. To see this, note that the items CVER4, CHOR3 and CWITH3 contribute to the construction of the "colleague" part of the third axis.
} 
constraints. We observe that the correlations of RIMM with the items that contribute the most to the first axis are all significant and positive. Vice versa, the absence of time pressure on the work rhythm (RNOP), that play a part in the construction of the second axis, is negatively correlated with those items. This leads to a sixth proposition.

Proposition 6: High time pressure imposed on work rhythm by the market is positively correlated with involvement in information processing and decision.

If the response to the market has to be immediate, the best thing is to let the worker react as quickly as he can and so hierarchical constraints need to be low or medium to leave space to a flexible response. Blue collars from firm B are in this situation. They make proposition for process improvement, participate in product testing and when a problem occurs in the course of production, they try to manage it with colleagues around them. The role of superiors is to help and give advice rather than to enforce permanent checks. However, in the case of firm B, workers communication network is limited to the boss and to close colleagues.

What field work has showed us here is that the labor force section of the COI survey gave useful information to better understand the nature of organizational change. Firm A did not seem very innovative in our business survey, but firm $A$ is a craft firm and organizational change does not have the same meaning in that case than in the three others. Firm $B$ had an intermediate position in terms of organizational change and it is also a firm dominated in a network of sub-contracting relations. Firm D is the most advanced in terms of organizational and it has focused its organizational strategy on services in order to escape the constraints of the economic cycle.

\subsection{Organizational innovation and workers' effort}

Is there a relation between organizational changes measured at the firm level and organizational characteristics of blue collar jobs? To give a first answer to this question, we simply correlated firms' coordinates on the two first axis of the firm level correspondence analysis and blue collars' coordinates on the three first axis of the worker level correspondence analysis, after choosing randomly one blue collar within each firm. Results are displayed in table 4 .

\section{[Insert table 4]}

We find that firms with an increasing use of "employee involvement" and "quality" practices have their blue collar workers more involved in information processing and decision and / or more constrained by technology and standards. Furthermore, work is influenced by colleagues rather than by the customer. Symmetrically this result means that in firms with no organizational changes blue collar workers communicate less with other people in or outside the firm and they work under hierarchical pressure rather than formalized quantitative or qualitative pressure. Thus, an increasing use of "high performance practices" is correlated 
both with higher autonomy or more decentralized information processing and with higher constraints on work due to automated technology, repetitive tasks and quality standards. The two following proposition summarizes these results:

Proposition 7: An increase in the use of "employee involvement" and "quality" practices declared by the firm is positively correlated with a higher intensity of blue collar workers' involvement in information processing and decision.

Proposition 8: An increase in the use of "employee involvement" and "quality" practices declared by the firm is also positively correlated with a higher intensity of technical constraint and with production flows that are pushed by colleagues rather than pulled by the market.

Furthermore, the second axis of the firm level correspondence analysis, which measures a stable use of new organizational practices, is not significantly correlated with any of the axis from the worker level correspondence analysis.

The linkage we find here between a high intensity of communication, which is part of the first axis of the worker level correspondence analysis, and organizational change is consistent with what Shaw, Gant and Ichniowki (1999) found in the steel industry in their paper for the conference. They argue that "a move to a high-performance workplace requires a reconfiguration of the entire system of inter-personal interactions in the workplace" (p.2). We can look a little closer at the workers' items that are the more correlated to the firms' items in our empirical analysis. Table 5 gives the correlations between the 5 items that we have selected on each of the 5 axis of the two correspondence analysis.

\section{[Insert table 5]}

We observe that an increase by 4 tasks and more in the number of tasks production workers are responsible for (PWI4_M) is positively correlated with a high level of communication both between workers from the same unit (CHOR3) and with other people in the firm (CWITH3) and with a large scope of initiative (SCOPI4). We also find that the 5 items associated with the first axis of the firm level correspondence analysis are positively correlated with blue collars' propositions for performance improvement (PPIMY). If we check the other worker level items that participate into the construction of the "intensity of involvement" axis, we find that the number of meetings attended by the worker has the same correlation profiles crossed with firm level items as propositions for process improvement: the attendance at more than one meeting a year in the context of work (MEET4) is positively correlated with the 5 firm level items of the first axis ${ }^{9}$. It is also noticeable that a stable use of new organizational practices between 1994 and 1997 is not correlated with our worker level items. This could be a sign that higher inter-personal interactions on the work place are more

\footnotetext{
${ }^{9}$ Correlations are very significant and range between 0.10 (increasing use of value analysis, functional analysis or "AMDEC" method) and 0.13 (increasing use of a system of just-in-time production).
} 
correlated to the context of change itself than to the practices used. This could be checked in some further field work.

The correlation of organizational change with the intensity of constraints and with the influence of colleagues (though weaker) tends to show that it takes place more frequently in "industrial" types of environment. In table 5, we observe that a high level in the intensity of technical constraints (CTECH3) is positively correlated with and increasing use of "employee involvement" and "quality practices" (AMDM, TPMM and PWI4_M). Tables 5 also shows that precise quantified quality norms imposed on blue collars (QUALY) are positively correlated with the 5 firm level items denoting increasing use of new organizational practices. We checked that the same kind of correlation profile is associated quality testing of products (TESTY). Furthermore, tight time constraints (RIMM) are not significantly correlated with the firm level items.

We have seen (proposition 3) that at the level of the worker, high involvement in information processing and decision was negatively correlated with high technical constraint. Thus, firms that implement organizational change have to deal with this internal contradiction. In some further work, we will check if intensity of involvement in information processing and decision and intensity of constraints correspond to different type of firms or to a specialization of jobs within firms.

Size could explain part of the observed correlation between firm and worker level variables. Firm level variables are all strongly correlated with size. Bigger firms have a more dynamic organization than smaller ones. In the firm level correspondence analysis, we checked, using size as a supplementary variable that the "no firms" were smaller than those with an increasing use of new organizational practices. However, worker level variables are much less sensitive to the size of the firm. It seems that the variables that structure the most strongly the space of blue collar job characteristics are independent from size. But looking more closely, we find that the worker level items that are significantly correlated with size are also correlated with organizational change: technical constraints, number of meetings, propositions for process improvement, quality norms and product testing. Furthermore "industrial" type of environments correspond to bigger firms that environment where work if pulled by the market or influenced by it.

What are the different explanations for the strong correlation with size in our firm level variables? A first one is mechanical: the probability of adopting a new organizational device is larger in a bigger firm as it would be larger in a firm made out of a collection of smaller ones. If this was true, it would be sounder to interview the plant rather than the firm. Second managerial vocabulary is better understood in bigger first where managers have more often been educated in schools where management research was going on. Third, organizational changes are responses to increased complexity either originating from inside the firm (introduction of new technologies, product differentiation, higher quality standards, etc.) or 
from outside (distant markets, customer with changing tastes etc.). In both cases, size makes increased complexity more complex, because coordination problems are bigger to solve.

To check if our firm / worker correlation may be explained by a pure size effect, we computed the correlation in table 4 again using data centered on the size/sector mean crossing 4 size categories and 15 sector ones. Results are still significant with the same sign, but they are a little weaker. Thus size and sector explains part of the observed correlation between firm and workers coordinates, but not all of it.

\section{Conclusion}

Using the COI survey, we have been able to measure different dimensions of organizational change both with firm level variables and with worker level variables. Our firm visits and post-survey interview gave us the feeling that although imprecise on a lot of points of view, we could trust our statistical data. We also found that the labor force section of the COI survey gave some useful information to better characterize the firm's activity and the consequences of organizational change on the content of work. Finally, we found that the firms that were more prone to organizational change had a bigger size, were "industrial" in the traditional sense of it (repetitive work, high capital intensity) and had developed dense internal communication network. These firms seem to search a way of better mastering quality rather than a way to give quicker response market demand.

We plan to pursue this analysis towards testing the performance impact of organizational change using micro-data that allows building up a production function. At the firm level, we found that new organizational practices were clustering. As underlined by Athey and Stern (1998), if we want to correctly assess the performance impact of organizational changes, it is important to understand why the firm has decided to adopt several practices and how this adoption process sequenced in time.

In the four firms that we visited, what appeared important in change adoption were macro shocks, the firm's own history and outside constraints weighing on her. During the period surveyed (1994-1997), firms B, C and D had suffered from a common shock ${ }^{10}$ : the 1993 recession. Observed organizational changes were partly a response to this shock because it brought about greater requirements from car manufacturers in firm B, because it lead to a change in owners in firm $\mathrm{C}$ and because it nurtured a new strategy to lower the effects of the macro cycle in firm $D$. In firm $A$, the shock came later on, originating from a change of

\footnotetext{
${ }^{10}$ As we visited the firms, we saw that they were adapting to three certain shocks lying ahead: the bug of the millenium and the transition to Euro, driving IT investments and the law on the 35 hours, leading to some changes in the organization of working times.
} 
strategy of its main customer leading to bankruptcy ${ }^{11}$. If organizational change is a response to difficult times, then it should be followed by performance improvement if the firm survives.

If we consider now the content of organizational choices, firm D seems to be the only firm in the four that really chose what changes she was going to implement. Leader in her market, backed up by a powerful group firm D had a lot of scope for choices. Changes were implemented progressively through an organization in projects. The only obstacle lied in the lack of "project" competencies, that is people bringing new ideas and able to lead a group and to get involved in network activities. This bottleneck determined the pace of organizational change. Thus firm D comforts at the same time the "functionalist" story and the "constructivist" story.

The internal organization of firm $\mathrm{C}$ changed within a very short time period: 6 month according to the financial director we interviewed. Organization in islets, just-in-time production and changes in the commercial network were implemented at the same time. Three years later, the firm obtained an ISO 9002 quality registration. This was decided by the new owner, an engineer who had taken up and expanded his father's firm where he had already implemented with success these changes. He imposed his views with charismatic authority through weekly meetings at firm $\mathrm{C}$ but he did not try to break the culture by changing the team of executives. This was gratefully acknowledged by our interlocutor. The new entity that absorbed firm $\mathrm{C}$ will be less sensitive to the cycle, because of its presence on two very different markets: manufacturing industry and agriculture. We could connect this case with the "functionalist" story.

We do not know what kind of changes were implemented in firm $\mathrm{A}$ once it was taken over. But like firm B, firm A relied heavily on one customer. This is why, the flavor of their story is more "radical". The development of the foundry activity could have helped firm A in being less dependant, but the shock that hurt her had not been anticipated. On the other hand, we cannot say that firm A wasn't efficient in its productive activities and her know-how was widely recognized in the profession. After the bankruptcy, the firm recovered quickly and the new owner did not have to layoff any workers. In fact, the car manufacturer at the origin of the shock changed its strategy shortly afterwards because he found out that he did not have the competencies necessary to pursue the prototyping activity in house.

In firm B, organizational changes have been imposed by car manufacturers. She is owned by an engineer who insisted on having good equipment. Quality had always been an important competitive advantage and seemed to the mastered (except for one small part of the process). So when quality registration was imposed, it was not a big deal. Organization in islets and just in time delivery were also imposed a few years earlier. At the same time, car manufacturers

\footnotetext{
$"$ We will try to follow up this firm to check if the new owners decided to implement some organizational change.
} 
required cuts in prices, and lately, these cuts had to be justified by planned productivity gains through new changes in organization or process. Firm B relies on three different markets, so pressure on one of them could favor improvements benefiting to the two others were margins are bigger. But this did not seem to happen. The pressure imposed by car manufacturers focuses all the attention on one market where margins are shrinking. One of our interlocutors confessed that work rhythm would have to increase at the same time as higher involvement in intellectuals task and this was going to be a problem. As we already stressed it, performance improvements in firm B does not secure its survival and will not be noticeable in firm level data where production prices are not measured, but it increases the profit of order givers.

To sum up, it seems that constraints weighing on firms have to be properly measured in assessing the organizational design function of the firm. Moreover, employer / employee data sets of the type of the COI survey are useful to go deeper into the nature of organizational change as it allows to relate the worker's effort with the type of practice implemented by the firm. This linkage is important both because it defines the size of potential productivity gains and because it is a source of tensions that may impede performance.

\section{REFERENCES:}

Athey S. and Stern S. (1998): «An Empirical Framework for Testing Theories about Complementarity in Organizationa Design », NBER Working Paper, N6600, June.

Askenazy P. (1998) : "The néo-stakhanovism ", Communication to the conference on "Information and Communication Technologies, Employment and Earnings », Nice, 22 et 23 juin 1998.

Cézard M., Dussert F., Gollac M. (1992): "Taylor va au marché: organisation du travail et informatique", Travail et Emploi, N54, pp. 4-19.

Beckmann M. J. (1977) : "Management Production Functions and the Theory of the Firm », Journal of Economic Theory, Vol. 14, pp. 1-18.

Black S. E. Lynch L. M. (1997): «How to Compete: the Impact of Workplace Practices and Information Technology on Productivity », NBER Working Paper, N6120, August.

Brynjolfsson E. and L. M. Hitt (1997): «Information Technology and Productivity: Micro Evidence », Mimeo, January.

Cappelli P., Bassi L., Katz H., Knoke D. Osterman P. and Useem M. (1997): Change at Work, New York, Oxford University Press. 
Coutrot T. (1996): "Relations sociales et performances économiques, une première analyse empirique du cas français », Travail et Emploi, $\mathrm{N}^{\circ} 66$, Vol.1.

European Foundation for the Improvement of Living and Working Conditions (1998): «Les nouvelles formes d'organisation du travail : l'Europe peut-elle réaliser son potentiel? Résultats d'une enquête sur la participation directe en Europe »

Foray and Mairesse (Eds) (1999): Innovation et Performances: approches interdisciplinaires, Paris, Editions de l'EHESS.

Gollac M. (1989): « Les dimensions de l'organisation du travail: communications, autonomie et pouvoir hiérarchique », Economie et Statistique, $\mathrm{N}^{\circ} 224$, septembre, pp. 27-44.

Gollac M. et Volkoff S. (1996): «Citius, altius, fortius: l'intensification du travail », Actes de la Recherche en Sciences Sociales, Nº114, septembre, pp. 54-67.

Greenan N. (1997a): «Innovation technologique, changements organisationnels et évolution des compétences », Economie et Statistique, N²98, pp. 15-29, 1996 - 8.

Greenan N. (1997b): «Progrès technologique et changements organisationnels : leur impact sur l'emploi et les qualifications », Economie et Statistique, N²98, pp. 35-44, 1996 - 8.

Greenan N. and Guellec D. (1998): «Firm Organization, Technology and Performance: An Empirical Study », Economic of Information and New Technologies, Vol. 6, pp. 313-347.

Greenan N. and Mairesse J. (1996): "Computers and Productivity in France: Some Evidence ", NBER Working Paper, N5836, November 1996, to be published in Economics of Innovation and New Technology, 1998.

Harris D. (Ed) (1994): Organizational Linkages: Understanding the Productivity Paradox, Washington D. C., National Academy Press.

Ichniowski C., Shaw K. and Prennushi G. (1997): "The Effects of Human Resource Management Practices on Productivity: a Study of Steel Finishing Lines », American Economic Review, Vol. 87, N³, June, pp. 291-313.

Keren M. and Levhari D. (1989) : «Decentralization, Aggregation, control Loss and Costs in a Hierarchical Model of the Firm », Journal of Economic Behavior and Organization, $\mathrm{N}^{\circ} 11$, pp. 213-236.

Kramarz F. (1986): "Conditions de travail et gestion de la main d'œuvre ouvrière », Economie et Statistique, $\mathrm{N}^{\circ} 186$, mars, pp. 31-45. 
Kremer M. (1993) : "The O-Ring Theory Of Economic development », Quarterly Journal of Economics, Vol. CVIII, N³, August, pp. 551-575.

Mairesse J. and Greenan N. (1998): "Using Information Collected from Employees in an Econometric Study of Firms : Is One Employee Enough? » Preliminary paper to be presented at The International Symposium on Employer-Employee Matched Data (Washington, May 22-23 1998).

Maurice, Sellier and Silvestre (1982): Politique d'éducation et organisation industrielle en France et en Allemagne, Paris, PUF.

Miller D. and Friesen P. H. (1984): Organization: A Quantum view, Prentice-Hall, Englewood Cliffs, New Jersey.

Milgrom P. et Roberts J. (1990) : "The Economic of Modern Manufacturing: Technology, Strategy, and Organization », American Economic Review, Vol. 80, N³, June, pp. 511 528.

OECD (1999): "Flexible Working Practices: Where are they Found and What are their Labour Market Implication », Draft for the working party on employment, 6-7 April 1999.

Salais R. (1992) : «Modernisation des entreprises et Fonds National de l'Emploi : une analyse en terme de mondes de production ", Travail et Emploi, N51, pp. 49-68.

Shaw K., Gant J. and Ichniowki C. (1999) : "The Evolution Towards High-Involvement Organization: Distinguishing Differences in Workers' Networks », prepared for the NBER conference on organizational change and performance improvement, Santa Rosa, April 2324. 


\section{BOX 1 : Questions from the business section of the COI survey}

For the purpose of our study, we selected the following four sets of questions. We present them using the order chosen in the questionnaire:

1. Does your company use the following organizational device?

\begin{tabular}{|c|c|c|c|c|c|c|}
\hline \multicolumn{2}{|c|}{ 1. Does your company use the following organizational device? } & \multicolumn{2}{|c|}{ In 1997} & \multicolumn{3}{|c|}{$\begin{array}{c}\text { Change in the percentage } \\
\text { of employees affected } \\
\text { since } 1994\end{array}$} \\
\hline$(\mathbf{X X X})^{\star}$ & Name of the organizational device & Yes & No & + & $=$ & - \\
\hline (ISO) & ISO 9001, ISO 9002, EAQF certification & $50.3 * *$ & 49.7 & 31.3 & 37.9 & 0.8 \\
\hline (TQM) & Other certification or total quality management & 32.7 & 67.3 & 17.9 & 81.2 & 0.8 \\
\hline (AMD) & Value analysis, functional analysis or "AMDEC" method & 28.1 & 71.9 & 14.1 & 85.3 & 0.6 \\
\hline (TPM) & 5S method or TPM (Total Productive Maintenance) & 16.6 & 83.4 & 9.9 & 89.5 & 0.6 \\
\hline (OPC) & Organization in profit centers & 31.4 & 68.6 & 10.8 & 88.7 & 0.5 \\
\hline$(\mathrm{CSC})$ & Formal in-house customer / supplier contracts & 28.6 & 71.4 & 13.1 & 86.5 & 0.4 \\
\hline (DJIT) & System of just in time delivery & 38.9 & 61.1 & 18.6 & 80.9 & 0.5 \\
\hline (PJIT) & System of just in time production & 37.8 & 62.2 & 18.3 & 81.3 & 0.4 \\
\hline
\end{tabular}

The 8 variables constructed from each line take three items (noted XXXN, XXXS, XXXM): the organizational device is not used by the firm in 1997 and the percentage of employees affected has remained stable or has decreased since 1994, the device is used in 1997 and the percentage of employees affected remained stable or has decreased, the device concerns a greater share of workers in 1997 than in 1994. The way this question has been formulated has a draw back as we cannot distinguish firms that have implemented a device for the first time between 1994 and 1997 and firms that had it already in 1994 and that extended its use.

2. In 1997, what percentage of company employees took part in the following types of teams or groups of ...

\begin{tabular}{|c|c|c|c|c|c|c|c|}
\hline & \multicolumn{3}{|c|}{ Production workers } & \multicolumn{3}{|c|}{ Other workers } \\
\hline$(\mathbf{X X X})$ & Name of the type of group & $0 \%-10 \%$ & $10 \%-50 \%$ & + de $50 \%$ & $0 \%-10 \%$ & $10 \%-50 \%$ & + de $50 \%$ \\
\hline (AWT) & Autonomous work teams & 71.5 & 18.1 & 10.3 & 74.3 & 18.6 & 7.1 \\
\hline (PSG) & Problem solving groups & 72.7 & 23.8 & 3.6 & 68.2 & 25.9 & 5.9 \\
\hline (PRG) & Project teams & 82.7 & 15.0 & 2.3 & 68.8 & 25.3 & 5.9 \\
\hline
\end{tabular}

The variables (3 variables) constructed from each line take four modalities (noted XXXLL, XXXML, XXXLM, XXXMM): less than $10 \%$ of the production workers and of the other workers participate in the group in 1997, more than $10 \%$ of the production workers and less than $10 \%$ of the other workers participate in the group, less than $10 \%$ of the production workers and more than $10 \%$ of the other workers participate in the group in 1997, more the $10 \%$ of the two types of workers participate in the group. 
3. In general, who is/was authorized to do the following in

your company workshops?

(more than one answer possible)

Adjust installations

Perform $1^{\text {st }}$ level maintenance

Allocate tasks to production workers

Inspect quality of supplies

Inspect quality of production

Participate in performance improvements

Participate in projects teams

Stop production in case of an incident

Troubleshoot in case of an incident

Start production again in case of an incident

\begin{tabular}{|c|c|c||c|c|c|}
\hline \multicolumn{3}{|c||}{ In 1997 } & \multicolumn{3}{c|}{ In 1994 } \\
\hline $\begin{array}{c}\text { Hierarchy } \\
\text { (HIE) }\end{array}$ & $\begin{array}{c}\text { Production } \\
\text { worker (PW) }\end{array}$ & $\begin{array}{c}\text { Specialist } \\
\text { (SPE) }\end{array}$ & $\begin{array}{c}\text { Hierarchy } \\
\text { (HIE) }\end{array}$ & $\begin{array}{c}\text { Production } \\
\text { worker (PW) }\end{array}$ & $\begin{array}{c}\text { Specialist } \\
\text { (SPE) }\end{array}$ \\
\hline 23.3 & 56.8 & 49.3 & 25.5 & 48.8 & 50.0 \\
\hline 11.1 & 64.6 & 41.1 & 13.2 & 51.5 & 48.0 \\
\hline 85.0 & 9.6 & 7.5 & 86.2 & 6.2 & 7.1 \\
\hline 37.5 & 35.4 & 42.6 & 39.4 & 30.7 & 41.7 \\
\hline 46.6 & 53.5 & 40.5 & 49.2 & 41.3 & 41.7 \\
\hline 78.6 & 54.2 & 36.6 & 80.2 & 40.2 & 33.6 \\
\hline 70.5 & 39.1 & 37.3 & 70.9 & 28.6 & 33.7 \\
\hline 73.1 & 45.6 & 26.1 & 75.2 & 37.3 & 23.8 \\
\hline 54.8 & 45.4 & 42.3 & 57.8 & 36.3 & 40.6 \\
\hline 75.6 & 23.8 & 28.2 & 77.5 & 18.7 & 25.2 \\
\hline
\end{tabular}

Three variables have been constructed from this set of questions. Each variable takes four items designed according to the distribution of the numbers of tasks each type of worker is responsible for and to the distribution of the evolution in this number of tasks between 1994 and 1997. The variable for the hierarchy (HIE) takes the following items: increase in the number of tasks (HIEI), decrease (HIED), stability around 0 to 5 tasks (HIES0 5) and stability around 6 to 10 tasks (HIES6_M). For production workers (PW), items are: increase of 4 tasks and more (PWI4_M), increase of 1 to 3 tasks (PWI1_3), stability around 0 to 3 tasks (PWS0_3) and stability around 6 to 10 tasks (PWS4_M). At last, for specialists (SPE), items are: increase (SPEI), decrease (SPED), stability around 0 to 3 tasks (SPES0_3) and stability around 4 to 10 tasks (SPES4_10).

\begin{tabular}{|c|c|c|c|}
\hline $\begin{array}{l}\text { 4. How many hierarchical } \\
\text { (level N)? (HL) and (EVH) }\end{array}$ & e t & tion workers (level & of \\
\hline In $1997, N=1$ & 7.2 & In $1994, N=1$ & 7.8 \\
\hline $\mathrm{N}=\mathbf{2}$ & 21.4 & $\mathrm{~N}=2$ & 19.0 \\
\hline $\mathbf{N}=\mathbf{3}$ & 29.5 & $\mathbf{N}=\mathbf{3}$ & 27.4 \\
\hline $\mathbf{N}=4$ & 24.6 & $N=4$ & 23.9 \\
\hline $\mathbf{N}=\mathbf{5}$ & 11.8 & $N=5$ & 13.7 \\
\hline $\mathrm{N}=6$ and + & 5.5 & $N=6$ and + & 8.1 \\
\hline
\end{tabular}

Two variables have been constructed from these questions. The first one gives the number of hierarchical layers in 1997 (HL), grouped in four items 0 to 2 noted HL2, 3 noted HL3, 4 noted HL4 and 5 and more noted HL5. The second one gives a measure of the change in the number of hierarchical layers between 1994 and 1997 (EVHL) in four items: increase (EVHLI), stability (EVHLS), loss of 1 layer (EVHLD1) and loss of 2 and more layers (EVHLD2).

(*) Between brackets and in capital letters are the names of the variables that are reported in tables and figures. An explanation of the items taken by each variable constructed for the purpose of our study is given after the displayed sets of questions.

$\left(^{* *}\right)$ For each set of questions, we give the percentage of manufacturing firms with more than 50 employees that ticked each cell computed from the sample of respondents (2758 firms) and using weights to adjust for sampling rates and non response. Frequency counts from the business part of the COI survey are published in Favre, François and Greenan (1998). The whole questionnaire and some descriptive results have been translated in English. They are available upon request. 


\section{BOX 2 : Questions from the labor force of the COI survey}

In this box, we give all the "primary" questions from the labor force questionnaire that we used for the purpose of this study. They are grouped together according to the different topics we want to measure. Thus, we do not follow the order of the questionnaire, but all the questions starting with the same letter come together in the questionnaire. Appendix 2 explains precisely how the synthetic variables have been constructed from the "primary" variables. In capital letters we give the names of the synthetic variables that are reported in tables and figures and the corresponding number of items. Most of the variables lead to a yes/no type of answer. When it is different, we mention it and "(if it applies)" indicates that there is also an item "does not apply". In between brackets, we give the percentage of blue collars belonging to manufacturing firms with more than 50 employees that gave a positive answer, using weights to adjust for sampling rates and non response (sample of 2157 workers).

1) Intensity of vertical communication (CVER, 5 items)

(a) Do you have occasion to modify the nature and quantity of the work which you will have to do, or the manner of proceeding ? If yes, is it...

$\left(a_{1}\right)$ while discussing with your superiors alone (if it applies)? (27.1\%)

$\left(a_{2}\right)$ while discussing with your superiors in the presence of your colleagues (if it applies)? (24.7\%)

(b) If you have a temporary excess workload or if you are uneasy with a difficult or tricky task are you helped by... (b) your superiors? (if it applies) $(44.1 \%)$

(c) In general, does your superior intervene...

$\left(c_{1}\right)$ to show you how to do the work? (30.7\%)

$\left(c_{2}\right)$ to share the work between you and your colleagues? (if it applies) $(64.0 \%)$

$\left(\mathbf{c}_{3}\right)$ when you have a problem with a customer? (if it applies) $(10.0 \%)$

$\left(\mathbf{c}_{4}\right)$ when you have a technical problem? (if it applies) $(74.4 \%)$

$\left(\mathbf{c}_{5}\right)$ when you have relations problem with colleagues from the same department? (if it applies) $(56.0 \%)$

$\left(\mathbf{c}_{6}\right)$ when you have relation problem with other departments (if it applies) $(50.0 \%)$

2) Intensity of horizontal communication (CHOR, 4 items)

(a) Do you have occasion to modify the nature and quantity of the work which you will have to do, or the manner of proceeding ? If yes, is it...

$\left(a_{3}\right)$ while discussing between colleagues, without your superiors being present (if it applies) ? $(22.9 \%)$

(b) If you have a temporary excess workload or if you are uneasy with a difficult or tricky task are you helped by...

$\left(\mathbf{b}_{2}\right)$ colleagues you usually work with? (if it applies) (77.5\%)

(d) Do you give indications to other persons on what they have to do...

$\left(d_{1}\right)$ to colleagues you usually work with? (if it applies) (73.8\%)

(e) Apart from your superiors, are there other persons that give you indications on what you have to do:

$\left(\mathbf{e}_{1}\right)$ colleagues you usually work with? (if it applies) $(54.5 \%)$

3) Intensity of communication with other departments (CWITH, 4 items)

(a) Do you have occasion to modify the nature and quantity of the work which you will have to do, or the manner of proceeding ? If yes, is it...

$\left(\mathbf{a}_{4}\right)$ while discussing with colleagues from other departments? (if it applies) $(6.7 \%)$

(b) If you have a temporary excess workload or if you are uneasy with a difficult or tricky task are you helped by..

$\left(\mathbf{b}_{3}\right)$ persons in the firm other than the colleagues you usually work with? (if it applies) $(19.5 \%)$

(d) Do you give indications to other persons on what they have to do...

$\left(d_{2}\right)$ other persons or departments in the firm? (if it applies) $(32.8 \%)$

(e) Apart from your superiors, are there other persons that give you indications on what you have to do...

$\left(\mathbf{e}_{2}\right)$ other persons or departments in the firm? (if it applies) $(32.5 \%)$

4) Intensity communication with outside the firm (CBETW, 3 items)

(b) If you have a temporary excess workload or if you are uneasy with a difficult or tricky task are you helped by...

$\left(\mathbf{b}_{4}\right)$ persons from outside the firm? (if it applies) $(8.9 \%)$

(d) Do you give indications to other persons on what they have to do...

$\left(d_{3}\right)$ persons from outside the firm (customers, suppliers, order-givers...)? $(11.8 \%)$

(e) Apart from your superiors, are there other persons that give you indications on what you have to do...

$\left(\mathrm{e}_{3}\right)$ persons from outside the firm (customers, suppliers, order-givers...)? $(6.8 \%)$

5) Intensity of contact with the customer (CUS, 3 items)

(m) Are you in direct contact (face to face or by phone) with customers? All the time (2.0\%), regularly (2.9\%), occasionally $(8.1 \%)$ or never $(87.0 \%)$. 
6) Number of meetings per year (MEET, 5 items)

(f) How frequently do you participate into meetings in the context of your work? (at least once a year: $57.3 \%$ )

7) Scope of initiative left by hierarchy (SCOPI, 5 items)

(a) Do you have occasion to modify the nature and quantity of the work which you will have to do, or the manner of proceeding ? (41.4\%)

(g) Instructions given by your superiors in the company tell you what must be done. In general do they also tell you how to do the work? $(30.2 \%)$ or do they tell you the objective of your work, but leave you to decide how to achieve this objective? $(69.8 \%)$

(h) You receive orders, assignments, instructions. In order to perform your work correctly, which of the following applies (if it applies) ? You carry the assignments to the letter (63.8\%). In certain cases, you act differently (31.0\%). You act differently most of the time $(2.5 \%)$.

(i) In general, when in the course of your work, something unforeseen occurs, what happens ? You fix the problem on your own $(42.7 \%)$. You manage it with the colleagues around you $(27.2 \%)$. You call on other people (a superior, a colleague, a specialist department) (30.1\%).

(j) Is your work rhythm imposed by the following?

$\left(\mathrm{j}_{1}\right)$ Permanent (or at least daily) checks or supervision by the hierarchy? $(41.8 \%)$

8) Propositions for process improvement (PPIM, 2 items)

(k) In the context of your work, do you make propositions in order to improve your post, processes or equipment? $(61.7 \%)$

9) Intensity of production work within a group (GROU, 4 items)

(l) Do you sometimes do your work in group or collectively? $(53.7 \%)$

$\left(\mathbf{l}_{1}\right)$ If yes, how much of your working time does it take? Almost all the time $(27.2 \%)$, more than $1 / 4$ of your time $(10.5 \%)$, less than $1 / 4$ of your time $(16.0 \%)$.

10) Work rhythm fixed by prescribed times (RXXX, 4 items)

(j) Is your work rhythm imposed by the following?

$\left(\mathrm{j}_{2}\right)$ Production norms or deadline to meet in an hour at most? $(36.7 \%)$

$\left(\mathrm{j}_{3}\right)$ Production norms or deadlines to meet in a day at most? $(61.4 \%)$

$\left(\mathrm{j}_{4}\right)$ External demand (customers) needing an immediate response? $(31.1 \%)$

$\left(\mathrm{j}_{6}\right)$ Immediate dependence of one or more colleagues in the work done? $(41.5 \%)$

11) Work rhythm fixed by horizontal linkages (RCXXX, 4 items)

(j) Is your work rhythm imposed by the following?

$\left(\mathrm{j}_{4}\right)$ External demand (customers) needing an immediate response? $(31.1 \%)$

( $\left.\mathrm{j}_{5}\right)$ External demand (customers) not needing an immediate response? (31.1\%)

$\left(\mathrm{j}_{6}\right)$ Immediate dependence of one or more colleagues in the work done? $(41.5 \%)$

12) Work rhythm fixed by technical constraints (RTEC, 3 items))

(j) Is your work rhythm imposed by the following?

$\left(\mathrm{j}_{7}\right)$ Automatic moving of a product or a part? $(33.6 \%)$

$\left(\mathbf{j}_{8}\right)$ Automatic pace of a machine $(42.4 \%)$

(n) Do your work consist in continually repeating the same series of actions or operations?

$\left(n_{1}\right)$ If yes, does each series last for lest than a minute? $(18.6 \%)$

13) Precise quality norms prescribed (QUAL, 2 items)

(o) Do you personally have to meet precise quantified quality standards (for example: wastage rates, measurable characteristics of the product) ? $(47.9 \%)$

14) Participation in product testing (TEST, 2 items)

(p) In the context of your work, do you sometimes get to test the quality of products or try them? $(50.4 \%)$ 
Table 1: What is measured through the answers of firm representatives and blue-collar workers?

\begin{tabular}{|c|c|}
\hline $\begin{array}{c}\text { Firm representative } \\
\text { Situation of the firm in } 1997 \text { and change } \\
\text { over the } 1994-1997 \text { period }\end{array}$ & $\begin{array}{c}\text { Blue-collar worker } \\
\text { Description of work content en } 1997\end{array}$ \\
\hline \multicolumn{2}{|c|}{ Information system: Decentralization of the hierarchical structure } \\
\hline $\begin{array}{c}\text { Existence and evolution in use of ... } \\
\text {...organization in profit centers } \\
\text { (OPC, } 3 \text { items) } \\
\text {... formal in house customer / supplier } \\
\text { contracts (CSC, } 3 \text { items) } \\
\text { Number of hierarchical layers (HL, } 5 \text { items) } \\
\text { Change in HL (EVHL, } 4 \text { items) }\end{array}$ & $\begin{array}{l}\text { Cannot be measured through questions addressed to blue } \\
\text { collar workers }\end{array}$ \\
\hline \multicolumn{2}{|c|}{ Information system : Involvement of employees in information processing and decision } \\
\hline $\begin{array}{c}\text { Extent in the use of... } \\
\text {...of problem solving groups (PSG, } 3 \text { items) } \\
\text {...of project groups (PRG, } 3 \text { items) } \\
\text { Existence and evolution in use of ... } \\
\ldots 5 \text { S method or TPM (TPM, } 3 \text { items) } \\
\text { Change in the number of operating tasks the } \\
\text { hierarchy (HIE, } 4 \text { items), the production } \\
\text { workers (PW, } 4 \text { items) and the specialists } \\
\text { (SPE, } 4 \text { items) are respectively responsible } \\
\text { for }\end{array}$ & $\begin{array}{c}\text { Intensity of... } \\
\text {...vertical communication (CVER, } 5 \text { items) } \\
\text {...horizontal communication (CHOR, } 4 \text { items) } \\
\text {...communication with other departments (CWITH, } 4 \\
\text { items) } \\
\text {...communication with outside the firm (CBETW, } 3 \text { items) } \\
\text {... contact with the customer (CUS, } 3 \text { items) } \\
\text { Number of meetings (MEET, } 5 \text { items) } \\
\text { Scope of initiative (SCOPI, } 5 \text { items) } \\
\text { Propositions for process improvements (PPIM, } 2 \text { items) }\end{array}$ \\
\hline \multicolumn{2}{|c|}{ Production system: individual or group as the primary work unit } \\
\hline $\begin{array}{l}\text { Extent in the use of autonomous work teams } \\
\text { (AWT, } 3 \text { items) }\end{array}$ & $\begin{array}{c}\text { Intensity of production work } \\
\text { within a group (GROU, } 4 \text { items) }\end{array}$ \\
\hline \multicolumn{2}{|c|}{ Production system: complementarities due to time schedule and production flows } \\
\hline $\begin{array}{l}\text { Existence and evolution in use of... } \\
\text {... a just in time delivery system } \\
\text { (DJIT, } 3 \text { items) } \\
\text {...a just in time production system } \\
\text { (PJIT, } 3 \text { items) }\end{array}$ & $\begin{array}{l}\text { Work rhythm fixed by prescribed times (RXXX, } 4 \text { items) } \\
\text { Work rhythm fixed by horizontal linkages (RCXXX, } 4 \\
\text { items) }\end{array}$ \\
\hline \multicolumn{2}{|c|}{ Production system: complementarities due to equipment or work process } \\
\hline $\begin{array}{l}\text { No question in COI } \\
\text { should be available from another survey }\end{array}$ & $\begin{array}{l}\text { Intensity of technical constraints on the work rhythm } \\
\text { (RTEC, } 3 \text { items) }\end{array}$ \\
\hline \multicolumn{2}{|c|}{ Production system: complementarities due to quality standards } \\
\hline $\begin{array}{c}\text { Existence an evolution in use of... } \\
\ldots . \text { ISO } 9001, \text { ISO 9002, EAQF (ISO, } 3 \text { items) } \\
\ldots \text { TQM or other quality norms } \\
\text { (TQM, } 3 \text { items) } \\
\text {... Value analysis or AMDEC method } \\
\text { (AMD, } 3 \text { items) }\end{array}$ & $\begin{array}{c}\text { Prescription of precise quality norms (QUAL, } 2 \text { items) } \\
\text { Product testing (TEST, } 2 \text { items) }\end{array}$ \\
\hline
\end{tabular}


Table 2: Correlation between the 5 items of the variables that contribute the most to the inertia of the first and the second axis of the firm level correspondence analysis

\begin{tabular}{|c|c|c|c|c|c|c|c|c|c|c|c|}
\hline \multirow{2}{*}{\multicolumn{2}{|c|}{$\begin{array}{l}\text { Number of } \\
\text { firms: } 1462\end{array}$}} & \multicolumn{5}{|c|}{ First axis } & \multicolumn{5}{|c|}{ Second axis } \\
\hline & & \multirow{2}{*}{\begin{tabular}{|c}
$\begin{array}{c}\text { AMDM } \\
(+)\end{array}$ \\
$\begin{array}{c}-0.22 \\
(0.00)\end{array}$
\end{tabular}} & \multirow{2}{*}{$\begin{array}{c}\begin{array}{c}\text { TPMM } \\
(+)\end{array} \\
n s\end{array}$} & \multirow{2}{*}{$\begin{array}{c}\begin{array}{c}\text { DJITM } \\
(+)\end{array} \\
n s\end{array}$} & \multirow{2}{*}{$\begin{array}{c}\begin{array}{c}\text { PJITM } \\
(+)\end{array} \\
\mathrm{ns}\end{array}$} & \multirow{2}{*}{\begin{tabular}{|c|c}
$\begin{array}{c}\text { PWI4_M } \\
(+)\end{array}$ \\
$\begin{array}{c}0.09 \\
(0.00)\end{array}$ \\
\end{tabular}} & \multirow{2}{*}{$\begin{array}{c}\begin{array}{c}\text { PJITS } \\
(+)\end{array} \\
0.20 \\
(0.00) \\
\end{array}$} & \multirow{2}{*}{$\begin{array}{c}\begin{array}{c}\text { DJITS } \\
(+)\end{array} \\
0.20 \\
(0.00)\end{array}$} & \multirow{2}{*}{$\begin{array}{c}\begin{array}{c}\text { TPMS } \\
(+)\end{array} \\
0.26 \\
(0.00)\end{array}$} & \multirow{2}{*}{$\begin{array}{c}\begin{array}{c}\text { CSCS } \\
(+)\end{array} \\
0.15 \\
(0.00)\end{array}$} & \multirow{2}{*}{$\begin{array}{c}\begin{array}{c}\text { AMDS } \\
(+)\end{array} \\
1\end{array}$} \\
\hline \multirow{5}{*}{ 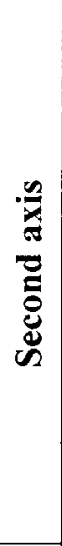 } & $\begin{array}{c}\text { AMDS } \\
(+) \\
\end{array}$ & & & & & & & & & & \\
\hline & $\begin{array}{c}\text { CSCS } \\
(+) \\
\end{array}$ & $\begin{array}{l}-0.07 \\
(0.01) \\
\end{array}$ & $\begin{array}{l}-0.04 \\
(0.14) \\
\end{array}$ & $\begin{array}{l}-0.08 \\
(0.00)\end{array}$ & $\begin{array}{c}-0.01 \\
(0.00)\end{array}$ & ns & $\begin{array}{c}0.25 \\
(0.00)\end{array}$ & $\begin{array}{c}0.26 \\
(0.00)\end{array}$ & $\begin{array}{c}0.21 \\
(0.00)\end{array}$ & 1 & \\
\hline & $\begin{array}{c}\text { TPMS } \\
(+)\end{array}$ & ns & $\begin{array}{c}-0.14 \\
(0.00) \\
\end{array}$ & $\begin{array}{l}-0.05 \\
(0.06) \\
\end{array}$ & $\begin{array}{l}-0.07 \\
(0.01) \\
\end{array}$ & $\begin{array}{c}0.07 \\
(0.01)\end{array}$ & $\begin{array}{c}0.23 \\
(0.00) \\
\end{array}$ & $\begin{array}{c}0.21 \\
(0.00)\end{array}$ & 1 & & \\
\hline & $\begin{array}{c}\text { DJITS } \\
(+)\end{array}$ & $\begin{array}{c}-0.09 \\
(0.00) \\
\end{array}$ & $\begin{array}{l}-0.06 \\
(0.02) \\
\end{array}$ & $\begin{array}{c}-0.30 \\
(0.00) \\
\end{array}$ & $\begin{array}{c}-0.26 \\
(0.00) \\
\end{array}$ & ns & $\begin{array}{c}0.68 \\
(0.00) \\
\end{array}$ & 1 & & & \\
\hline & $\begin{array}{c}\text { PJITS } \\
(+)\end{array}$ & $\begin{array}{l}-0.07 \\
(0.01)\end{array}$ & $\begin{array}{l}-0.06 \\
(0.02)\end{array}$ & $\begin{array}{l}-0.22 \\
(0.00)\end{array}$ & $\begin{array}{l}-0.28 \\
(0.00)\end{array}$ & ns & 1 & & & & \\
\hline \multirow{5}{*}{ 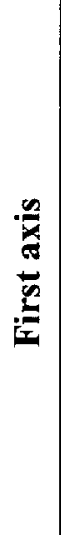 } & $\begin{array}{c}\text { PWI4_M } \\
(+)\end{array}$ & $\begin{array}{c}0.28 \\
(0.00)\end{array}$ & $\begin{array}{c}0.30 \\
(0.00) \\
\end{array}$ & $\begin{array}{c}0.16 \\
(0.00) \\
\end{array}$ & $\begin{array}{c}0.18 \\
(0.00) \\
\end{array}$ & 1 & & & & & \\
\hline & $\begin{array}{c}\text { PJITM } \\
(+)\end{array}$ & $\begin{array}{c}0.34 \\
(0.00) \\
\end{array}$ & $\begin{array}{c}0.32 \\
(0.00) \\
\end{array}$ & $\begin{array}{c}0.76 \\
(0.00) \\
\end{array}$ & 1 & & & & & & \\
\hline & $\begin{array}{c}\text { DJITM } \\
(+)\end{array}$ & $\begin{array}{c}0.37 \\
(0.00) \\
\end{array}$ & $\begin{array}{c}0.35 \\
(0.00) \\
\end{array}$ & 1 & & & & & & & \\
\hline & $\begin{array}{c}\text { TPMM } \\
(+)\end{array}$ & $\begin{array}{c}0.49 \\
(0.00)\end{array}$ & 1 & & & & & & & & \\
\hline & $\begin{array}{c}\text { AMDM } \\
(+)\end{array}$ & 1 & & & & & & & & & \\
\hline
\end{tabular}

AMD: value analysis, functional analysis or "AMDEC" methods

TPM: 5S method or TPM (Total Productive Maintenance)

DJIT: system of just in time delivery

PJIT: system of just in time production

CSC: formal in-house customer/supplier contracts

An M at the end of the item indicates an increase between 1994 and 1997 in the percentage of employees affected by the organizational device, whereas an $\mathbf{S}$ indicates a stable between use between these two dates.

PWI4_M: Increase between 1994 and 1997, by 4 tasks or more, in the number of tasks production workers are authorized to do.

Under the names items and in between brackets, we give the signs of coordinates in figure 1 .

Pearson correlation coefficients, in between brackets critical probabilities, ns indicates that the coefficient is non significant at a $15 \%$ level. 
Table 3: Correlation between the 5 items of the variables that contribute the most to the inertia of the first, second and the third axis of the worker level correspondence analysis?

\begin{tabular}{|c|c|c|c|c|c|c|c|c|c|c|c|}
\hline \multirow{2}{*}{\multicolumn{2}{|c|}{$\begin{array}{c}\text { Number of } \\
\text { blue collars: } \\
2157\end{array}$}} & \multicolumn{5}{|c|}{ First axis } & \multicolumn{5}{|c|}{ Second axis } \\
\hline & & $\begin{array}{c}\text { CVER4 } \\
(+)\end{array}$ & $\begin{array}{c}\text { CHOR3 } \\
(+)\end{array}$ & $\begin{array}{c}\text { CWITH3 } \\
(+)\end{array}$ & $\begin{array}{c}\text { SCOPI4 } \\
(+)\end{array}$ & $\begin{array}{c}\text { PPIMY } \\
(+)\end{array}$ & $\begin{array}{c}\text { CTEC3 } \\
(+)\end{array}$ & $\begin{array}{c}\text { QUALY } \\
(+)\end{array}$ & $\begin{array}{c}\text { CTEC0 } \\
(-)\end{array}$ & $\begin{array}{c}\text { CUS2 } \\
(-)\end{array}$ & $\begin{array}{c}\text { RNOP } \\
(-)\end{array}$ \\
\hline \multirow{5}{*}{ 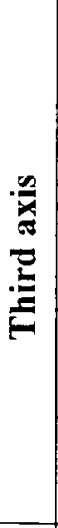 } & $\begin{array}{c}\text { RCUCO } \\
(+)\end{array}$ & $\begin{array}{c}0.07 \\
(0.00)\end{array}$ & $\begin{array}{c}0.05 \\
(0.04)\end{array}$ & $\begin{array}{c}0.07 \\
(0.00)\end{array}$ & $\begin{array}{c}0.05 \\
(0.02)\end{array}$ & $\begin{array}{c}0.08 \\
(0.00)\end{array}$ & $\begin{array}{l}-0.13 \\
(0.00)\end{array}$ & $\begin{array}{l}-0.13 \\
(0.00)\end{array}$ & $\begin{array}{l}-0.07 \\
(0.00)\end{array}$ & $\begin{array}{c}-0.07 \\
(0.00)\end{array}$ & $\begin{array}{c}0.30 \\
(0.00)\end{array}$ \\
\hline & $\begin{array}{c}\text { RCUS } \\
(+)\end{array}$ & $\begin{array}{c}0.06 \\
(0.00) \\
\end{array}$ & ns & ns & $\begin{array}{c}0.09 \\
(0.00)\end{array}$ & $\begin{array}{c}0.08 \\
(0.00) \\
\end{array}$ & $\begin{array}{c}-0.10 \\
(0.00)\end{array}$ & $\begin{array}{c}0.06 \\
(0.01) \\
\end{array}$ & $\begin{array}{c}0.08 \\
(0.00) \\
\end{array}$ & $\begin{array}{c}0.15 \\
(0.00)\end{array}$ & $\begin{array}{l}-0.16 \\
(0.00)\end{array}$ \\
\hline & $\begin{array}{c}\text { RIMM } \\
(+)\end{array}$ & $\begin{array}{c}0.14 \\
(0.00)\end{array}$ & $\begin{array}{c}0.08 \\
(0.00)\end{array}$ & $\begin{array}{c}0.11 \\
(0.00)\end{array}$ & $\begin{array}{c}0.11 \\
(0.00)\end{array}$ & $\begin{array}{c}0.11 \\
(0.00)\end{array}$ & $\begin{array}{c}0.03 \\
(0.12)\end{array}$ & $\begin{array}{c}0.10 \\
(0.00)\end{array}$ & $\begin{array}{l}-0.04 \\
(0.11)\end{array}$ & $\begin{array}{c}0.12 \\
(0.00)\end{array}$ & $\begin{array}{c}-0.39 \\
(0.00)\end{array}$ \\
\hline & $\begin{array}{c}\text { RCUCN } \\
(-)\end{array}$ & $\begin{array}{l}-0.09 \\
(0.00)\end{array}$ & $\begin{array}{l}-0.04 \\
(0.09)\end{array}$ & $\begin{array}{l}-0.06 \\
(0.01)\end{array}$ & $\begin{array}{l}-0.05 \\
(0.02)\end{array}$ & $\begin{array}{l}-0.07 \\
(0.00)\end{array}$ & $\begin{array}{c}0.11 \\
(0.00)\end{array}$ & $\begin{array}{c}0.06 \\
(0.00)\end{array}$ & $\begin{array}{c}0.10 \\
(0.00)\end{array}$ & ns & $\begin{array}{l}-0.20 \\
(0.00)\end{array}$ \\
\hline & $\begin{array}{c}\text { RCOL } \\
(-)\end{array}$ & ns & ns & ns & $\begin{array}{l}-0.08 \\
(0.00)\end{array}$ & $\begin{array}{l}-0.07 \\
(0.00)\end{array}$ & $\begin{array}{c}0.14 \\
(0.00)\end{array}$ & ns & $\begin{array}{l}-0.12 \\
(0.00)\end{array}$ & $\begin{array}{c}-0.09 \\
(0.00)\end{array}$ & ns \\
\hline \multirow{5}{*}{ 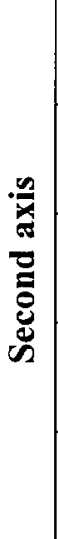 } & $\begin{array}{l}\text { RNOP } \\
(-)\end{array}$ & $\begin{array}{l}-0.05 \\
(0.03)\end{array}$ & ns & $\begin{array}{l}-0.03 \\
(0.14)\end{array}$ & ns & $\begin{array}{l}-0.07 \\
(0.00)\end{array}$ & $\begin{array}{l}-0.12 \\
(0.00)\end{array}$ & $\begin{array}{l}-0.09 \\
(0.00)\end{array}$ & $\begin{array}{c}0.15 \\
(0.00)\end{array}$ & ns & 1 \\
\hline & $\begin{array}{c}\text { CUS2 } \\
(-)\end{array}$ & $\begin{array}{c}0.08 \\
(0.00) \\
\end{array}$ & $\begin{array}{c}0.05 \\
(0.02)\end{array}$ & $\begin{array}{c}0.11 \\
(0.00)\end{array}$ & $\begin{array}{c}0.15 \\
(0.00) \\
\end{array}$ & ns & $\begin{array}{l}-0.10 \\
(0.00)\end{array}$ & $\begin{array}{l}-0.08 \\
(0.00)\end{array}$ & $\begin{array}{c}0.15 \\
(0.00) \\
\end{array}$ & 1 & \\
\hline & $\begin{array}{c}\text { CTEC0 } \\
(-)\end{array}$ & ns & ns & $\begin{array}{c}0.07 \\
(0.00)\end{array}$ & $\begin{array}{c}0.11 \\
(0.00)\end{array}$ & ns & $\begin{array}{l}-0.58 \\
(0.00)\end{array}$ & $\begin{array}{l}-0.15 \\
(0.00)\end{array}$ & 1 & & \\
\hline & $\underset{(+)}{\text { QUALY }}$ & $\begin{array}{c}0.06 \\
(0.00)\end{array}$ & $\begin{array}{c}0.04 \\
(0.07)\end{array}$ & ns & ns & $\begin{array}{c}0.17 \\
(0.00)\end{array}$ & $\begin{array}{c}0.09 \\
(0.00)\end{array}$ & 1 & & & \\
\hline & $\begin{array}{c}\text { CTEC } 3 \\
(+)\end{array}$ & $\begin{array}{l}-0.04 \\
(0.06)\end{array}$ & $\begin{array}{l}-0.03 \\
(0.15)\end{array}$ & $\begin{array}{l}-0.05 \\
(0.03)\end{array}$ & $\begin{array}{l}-0.09 \\
(0.00)\end{array}$ & ns & 1 & & & & \\
\hline \multirow{5}{*}{ 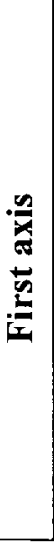 } & $\begin{array}{l}\text { PPIMY } \\
\qquad(+)\end{array}$ & $\begin{array}{c}0.15 \\
(0.00)\end{array}$ & $\begin{array}{c}0.13 \\
(0.00)\end{array}$ & $\begin{array}{c}0.14 \\
(0.00)\end{array}$ & $\begin{array}{c}0.13 \\
(0.00)\end{array}$ & 1 & & & & 1 & $\underset{(-)}{\operatorname{RCOL}}$ \\
\hline & $\begin{array}{c}\text { SCOPI4 } \\
(+)\end{array}$ & $\begin{array}{c}0.28 \\
(0.00) \\
\end{array}$ & $\begin{array}{c}0.28 \\
(0.00)\end{array}$ & $\begin{array}{c}0.18 \\
(0.00)\end{array}$ & 1 & & & & 1 & $\begin{array}{l}-0.38 \\
(0.00)\end{array}$ & $\underset{(-)}{\operatorname{RCUCN}}$ \\
\hline & $\begin{array}{c}\text { CWITH3 } \\
(+)\end{array}$ & $\begin{array}{c}0.25 \\
(0.00) \\
\end{array}$ & $\begin{array}{c}0.31 \\
(0.00) \\
\end{array}$ & 1 & & & & 1 & $\begin{array}{c}0.43 \\
(0.00)\end{array}$ & $\begin{array}{l}-0.36 \\
(0.00) \\
\end{array}$ & $\underset{(+)}{\operatorname{RIMM}}$ \\
\hline & $\begin{array}{c}\text { CHOR3 } \\
(+)\end{array}$ & $\begin{array}{c}0.40 \\
(0.00)\end{array}$ & 1 & & & & 1 & $\begin{array}{c}0.51 \\
(0.00)\end{array}$ & $\begin{array}{l}-0.42 \\
(0.00)\end{array}$ & $\begin{array}{l}-0.30 \\
(0.00)\end{array}$ & $\underset{(+)}{\text { RCUS }}$ \\
\hline & $\begin{array}{c}\text { CVER4 } \\
(+) \\
\end{array}$ & 1 & & & & 1 & $\begin{array}{l}-0.28 \\
(0.00)\end{array}$ & $\begin{array}{l}-0.50 \\
(0.00)\end{array}$ & $\begin{array}{l}-0.35 \\
(0.00)\end{array}$ & $\begin{array}{c}-0.25 \\
(0.00)\end{array}$ & $\underset{(+)}{\text { RCUCO }}$ \\
\hline & & & & & & $\begin{array}{c}\text { RCUCO } \\
(+)\end{array}$ & $\begin{array}{c}\text { RCUS } \\
(+)\end{array}$ & $\begin{array}{c}\text { RIMM } \\
(+)\end{array}$ & $\begin{array}{c}\text { RCUCN } \\
(-)\end{array}$ & $\begin{array}{c}\text { RCOL } \\
(-)\end{array}$ & \multirow{2}{*}{$\begin{array}{c}\text { Number of } \\
\text { Blue collars: } \\
2157\end{array}$} \\
\hline & & & & & & & & hird axis & & & \\
\hline
\end{tabular}

Explanations about the variables and their items are given in box 2 and in appendix 2.

Under the names items and in between brackets, we give the signs of coordinates in figure 2 and 3 .

Pearson correlation coefficients, in between brackets critical probabilities, ns indicates that the coefficient is not significant at a $15 \%$ level. 
Table 4 : Blue collar workers and firm representatives: how do answers correlate?

\begin{tabular}{|c|c|c|c|}
\hline $\begin{array}{l}\qquad N=1462 \\
\text { Coordinates of firm representatives }\end{array}$ & \multicolumn{3}{|c|}{$\begin{array}{c}\text { Coordinates of blue-collar workers } 1 \text { blue-collar } \\
\text { worker randomly chosen by firm }\end{array}$} \\
\hline Correlations on coordinates & $\begin{array}{l}\text { Intensity of } \\
\text { employee } \\
\text { involvement }\end{array}$ & $\begin{array}{l}\text { Intensity of } \\
\text { constraints }\end{array}$ & $\begin{array}{c}\text { Customers and } \\
\text { colleagues }\end{array}$ \\
\hline $\begin{array}{l}\text { Increasing use of "employee involvement" and } \\
\text { "quality" practices vs. no practice in } 1997\end{array}$ & $\begin{array}{c}0.16 \\
(0.00)\end{array}$ & $\begin{array}{c}0.13 \\
(0.00)\end{array}$ & $\begin{array}{l}-0.08 \\
(0.00)\end{array}$ \\
\hline $\begin{array}{c}\text { Innovative practices in 1997, stable in time vs. } \\
\text { increasing use of "JIT" practices }\end{array}$ & $\begin{array}{l}-0.03 \\
(0.23)\end{array}$ & $\begin{array}{l}-0.016 \\
(0.53)\end{array}$ & $\begin{array}{l}-0.02 \\
(0.53)\end{array}$ \\
\hline $\begin{array}{l}\text { Same with coordinate centered } \\
\text { on the size } x \text { sector mean }\end{array}$ & $\begin{array}{c}\text { Intensity of } \\
\text { employee } \\
\text { involvement }\end{array}$ & $\begin{array}{l}\text { Intensity of } \\
\text { constraints }\end{array}$ & $\begin{array}{c}\text { Customers and } \\
\text { colleagues }\end{array}$ \\
\hline $\begin{array}{l}\text { Increasing use of "employee involvement" and } \\
\text { "quality" practices vs. no practice in } 1997\end{array}$ & $\begin{array}{c}0.11 \\
(0.00)\end{array}$ & $\begin{array}{c}0.10 \\
(0.00)\end{array}$ & $\begin{array}{l}-0.04 \\
(0.11)\end{array}$ \\
\hline $\begin{array}{c}\text { Innovative practices in } 1997, \text { stable in time vs. } \\
\text { increasing use of "JIT" practices }\end{array}$ & $\begin{array}{l}-0.01 \\
(0.77)\end{array}$ & $\begin{array}{l}-0.00 \\
(0.97)\end{array}$ & $\begin{array}{l}-0.00 \\
(0.86)\end{array}$ \\
\hline
\end{tabular}

Pearson correlation coefficients, in between brackets critical probabilities. 
Table 5 : Blue collar workers and firm representatives: how do answers correlate ? Correlations between items that contribute the most to the inertia of the axis in the two correspondence analysis

\begin{tabular}{|c|c|c|c|c|c|c|c|c|c|c|c|c|}
\hline \multirow{3}{*}{\multicolumn{3}{|c|}{$\begin{array}{c}\mathrm{N}=1462 \\
\text { One worker chosen } \\
\text { at random in each } \\
\text { firm }\end{array}$}} & \multicolumn{10}{|c|}{ Firm level correspondence analysis } \\
\hline & & & \multicolumn{5}{|c|}{ First axis } & \multicolumn{5}{|c|}{ Second axis } \\
\hline & & & \multirow{2}{*}{\begin{tabular}{|c}
$\begin{array}{c}\text { AMDM } \\
(+)\end{array}$ \\
$\mathrm{ns}$
\end{tabular}} & \multirow{2}{*}{$\begin{array}{c}\begin{array}{c}\text { TPMM } \\
(+)\end{array} \\
\mathrm{ns}\end{array}$} & \multirow{2}{*}{$\begin{array}{c}\begin{array}{c}\text { DJITM } \\
(+)\end{array} \\
\mathrm{ns}\end{array}$} & \multirow{2}{*}{$\begin{array}{c}\begin{array}{c}\text { PJITM } \\
(+)\end{array} \\
\text { ns }\end{array}$} & \multirow{2}{*}{$\frac{\begin{array}{c}\text { PWI4_M } \\
(+)\end{array}}{n s}$} & \multirow{2}{*}{$\begin{array}{c}\text { PJITS } \\
(+)\end{array}$} & \multirow{2}{*}{$\begin{array}{c}\begin{array}{c}\text { DJITS } \\
(+)\end{array} \\
\mathrm{ns}\end{array}$} & \multirow{2}{*}{$\begin{array}{c}\text { TPMS } \\
(+)\end{array}$} & \multirow{2}{*}{$\begin{array}{c}\begin{array}{c}\text { CSCS } \\
(+)\end{array} \\
\text { ns }\end{array}$} & \multirow{2}{*}{$\begin{array}{c}\begin{array}{c}\text { AMDS } \\
(+)\end{array} \\
0.05 \\
(0.07)\end{array}$} \\
\hline \multirow{15}{*}{ 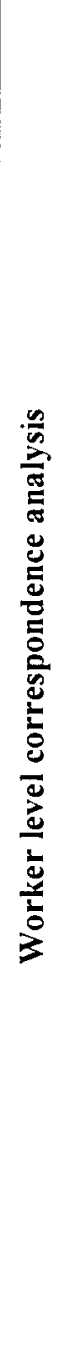 } & \multirow{5}{*}{ 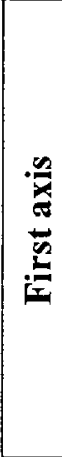 } & $\begin{array}{c}\text { CVER4 } \\
(+)\end{array}$ & & & & & & & & & & \\
\hline & & $\begin{array}{c}\text { CHOR3 } \\
(+)\end{array}$ & ns & $\begin{array}{c}0.06 \\
(0.03)\end{array}$ & ns & ns & $\begin{array}{c}0.05 \\
(0.05)\end{array}$ & ns & ns & ns & $\begin{array}{c}0.06 \\
(0.01)\end{array}$ & ns \\
\hline & & $\begin{array}{c}\text { CWITH3 } \\
(+)\end{array}$ & ns & ns & ns & ns & $\begin{array}{c}0.04 \\
(0.13)\end{array}$ & ns & ns & ns & $\begin{array}{c}0.05 \\
(0.06)\end{array}$ & ns \\
\hline & & $\begin{array}{c}\text { SCOPI4 } \\
(+)\end{array}$ & ns & ns & $\begin{array}{c}0.07 \\
(0.01)\end{array}$ & $\begin{array}{c}0.05 \\
(0.06)\end{array}$ & $\begin{array}{c}0.07 \\
(0.00)\end{array}$ & ns & ns & $\begin{array}{c}0.06 \\
(0.02)\end{array}$ & $\mathrm{ns}$ & ns \\
\hline & & $\begin{array}{c}\text { PPIMY } \\
(+) \\
\end{array}$ & $\begin{array}{c}0.12 \\
(0.00) \\
\end{array}$ & $\begin{array}{c}0.17 \\
(0.00) \\
\end{array}$ & $\begin{array}{c}0.08 \\
(0.00)\end{array}$ & $\begin{array}{c}0.08 \\
(0.00)\end{array}$ & $\begin{array}{c}0.11 \\
(0.00)\end{array}$ & ns & ns & ns & $\begin{array}{c}0.05 \\
(0.06)\end{array}$ & ns \\
\hline & \multirow{5}{*}{ 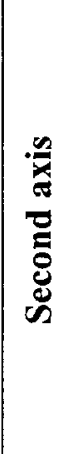 } & $\begin{array}{c}\text { CTEC3 } \\
(+)\end{array}$ & $\begin{array}{c}0.06 \\
(0.02)\end{array}$ & $\begin{array}{c}0.04 \\
(0.13)\end{array}$ & ns & ns & $\begin{array}{c}0.05 \\
(0.04)\end{array}$ & $\begin{array}{c}0.05 \\
(0.03)\end{array}$ & $\begin{array}{c}0.08 \\
(0.00)\end{array}$ & $\begin{array}{c}0.07 \\
(0.00)\end{array}$ & ns & ns \\
\hline & & $\begin{array}{c}\text { QUALY } \\
(+)\end{array}$ & $\begin{array}{c}0.05 \\
(0.05) \\
\end{array}$ & $\begin{array}{c}0.07 \\
(0.01)\end{array}$ & $\begin{array}{c}0.05 \\
(0.03)\end{array}$ & $\begin{array}{c}0.07 \\
(0.00)\end{array}$ & $\begin{array}{c}0.08 \\
(0.00)\end{array}$ & ns & ns & ns & ns & $\begin{array}{c}0.04 \\
(0.15)\end{array}$ \\
\hline & & $\begin{array}{c}\text { CTEC0 } \\
(-)\end{array}$ & $\begin{array}{c}-0.04 \\
(0.12)\end{array}$ & $\begin{array}{l}-0.05 \\
(0.08)\end{array}$ & ns & ns & ns & $\begin{array}{l}-0.05 \\
(0.06)\end{array}$ & $\begin{array}{c}-0.06 \\
(0.02)\end{array}$ & $\begin{array}{c}-0.06 \\
(0.01)\end{array}$ & ns & ns \\
\hline & & $\begin{array}{c}\text { CUS2 } \\
(-)\end{array}$ & ns & ns & $\begin{array}{c}0.01 \\
(0.07)\end{array}$ & ns & ns & $\begin{array}{c}-0.07 \\
(0.01)\end{array}$ & $\begin{array}{c}-0.04 \\
(0.13)\end{array}$ & $\begin{array}{c}0.04 \\
(0.09)\end{array}$ & $\begin{array}{c}0.05 \\
(0.07)\end{array}$ & $\begin{array}{c}0.06 \\
(0.03)\end{array}$ \\
\hline & & $\begin{array}{c}\text { RNOP } \\
(-)\end{array}$ & $\begin{array}{c}-0.05 \\
(0.04) \\
\end{array}$ & ns & $\begin{array}{c}-0.04 \\
(0.14)\end{array}$ & $\begin{array}{c}-0.05 \\
(0.04)\end{array}$ & ns & ns & ns & ns & ns & ns \\
\hline & \multirow{5}{*}{ 瓷 } & $\begin{array}{c}\text { RCUCO } \\
(+)\end{array}$ & ns & ns & ns & ns & ns & ns & ns & ns & ns & ns \\
\hline & & $\begin{array}{c}\text { RCUS } \\
(+)\end{array}$ & ns & ns & ns & ns & ns & $\begin{array}{c}-0.06 \\
(0.01)\end{array}$ & ns & $\mathrm{ns}$ & $\mathrm{ns}$ & $\mathrm{ns}$ \\
\hline & & $\begin{array}{c}\text { RIMM } \\
(+)\end{array}$ & $\begin{array}{c}0.05 \\
(0.05)\end{array}$ & ns & ns & ns & ns & $\begin{array}{c}-0.06 \\
(0.02)\end{array}$ & ns & $\mathrm{ns}$ & ns & $\mathrm{ns}$ \\
\hline & & $\begin{array}{c}\text { RCUCN } \\
(-)\end{array}$ & ns & ns & ns & $\mathrm{ns}$ & $\mathrm{ns}$ & $\begin{array}{c}-0.00 \\
(0.89)\end{array}$ & ns & $\mathrm{ns}$ & $\mathrm{ns}$ & $\mathrm{ns}$ \\
\hline & & $\begin{array}{c}\text { RCOL } \\
(-)\end{array}$ & ns & ns & ns & ns & $\mathrm{ns}$ & $\begin{array}{c}0.06 \\
(0.03)\end{array}$ & $\begin{array}{c}0.05 \\
(0.05)\end{array}$ & $\mathrm{ns}$ & $\mathrm{ns}$ & $\begin{array}{c}-0.04 \\
(0.12)\end{array}$ \\
\hline
\end{tabular}

AMD: value analysis, functional analysis or "AMDEC" methods

TPM: 5S method or TPM (Total Productive Maintenance)

DJIT: system of just in time delivery

PJIT: system of just in time production

CSC: formal in-house customer / supplier contracts

An M at the end of the item indicates an increase between 1994 and 1997 in the percentage of employees affected by the organizational device, whereas an $\mathbf{S}$ indicates a stable between use between these two dates.

PWI4_M: Increase between 1994 and 1997, by 4 tasks or more, in the number of tasks production workers are authorized to do.

Explanations about the worker level variables are given in box 2 and in appendix 2 .

Pearson correlation coefficients, in between brackets critical probabilities, ns indicates that the coefficient is not significant at a $15 \%$ level 


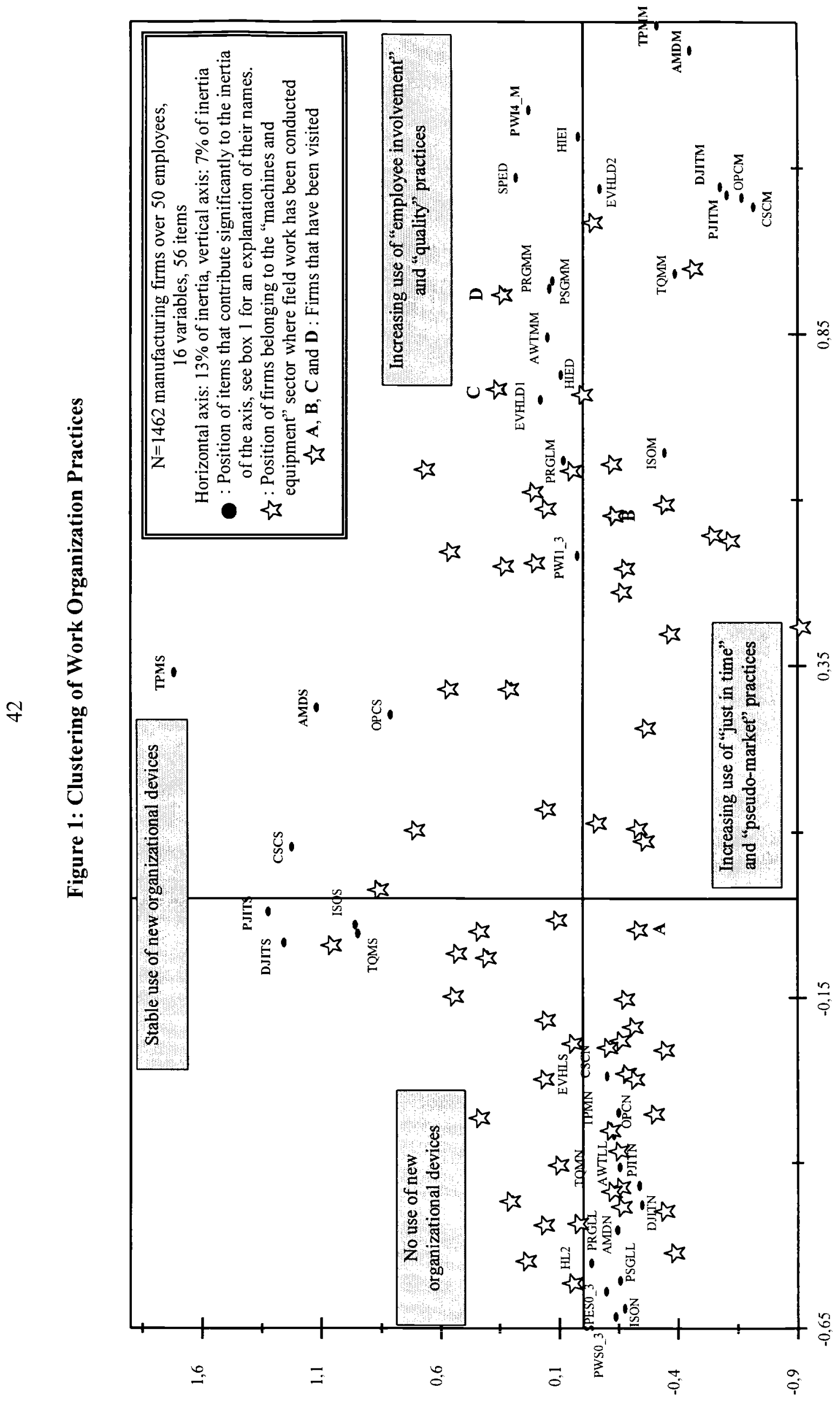




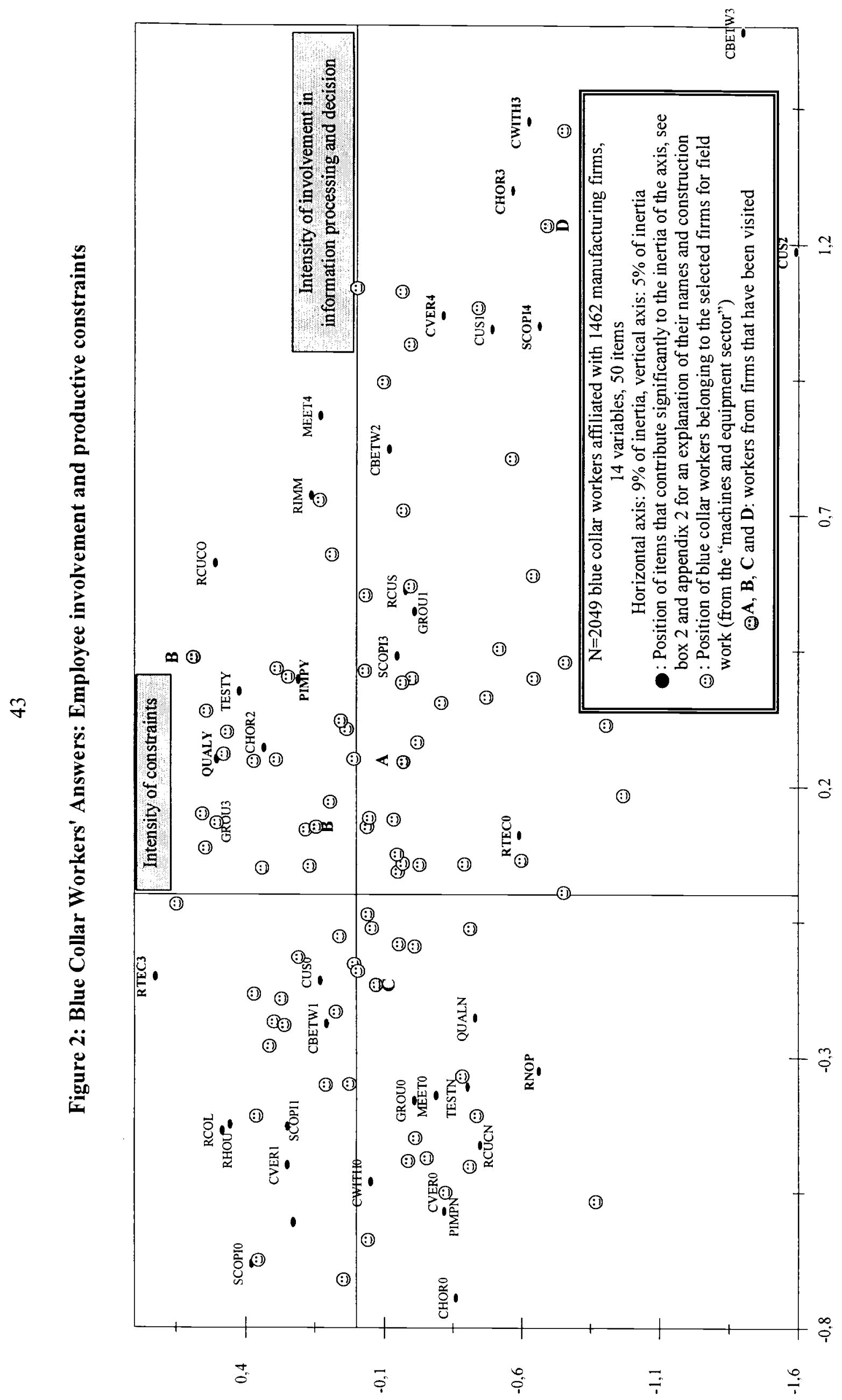




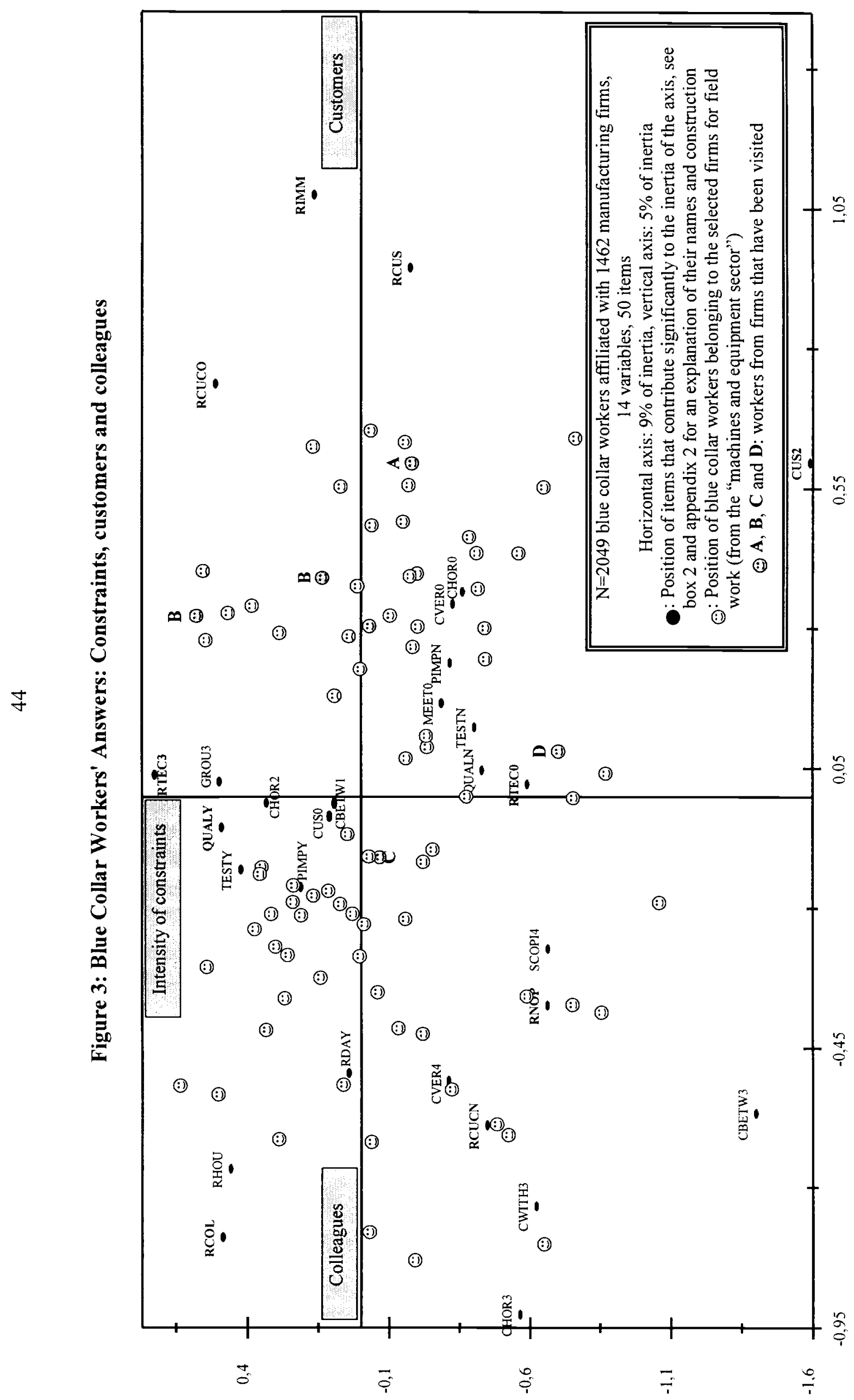


Appendix 1 : French and Anglo-saxon managerial practices: vocabulary

\begin{tabular}{|c|c|c|}
\hline English term & French term & Use of the term in France \\
\hline $\begin{array}{l}\text { Just-in-time } \\
\text { in production / delivery }\end{array}$ & $\begin{array}{l}\text { "juste-à-temps", "flux tendus" } \\
\text { "production"'/"livraison" }\end{array}$ & management / industry \\
\hline Employee involvement & $\begin{array}{l}\text { "implication des salaries" } \\
\text { "pratiques participatives" }\end{array}$ & government ("Auroux laws") \\
\hline Total quality management & "démarche de qualité totale" & management \\
\hline $\begin{array}{l}\text { ISO certification } \\
\text { Registered quality systems }\end{array}$ & certification ISO, EAQF & management \\
\hline Value analysis, value engineering & $\begin{array}{l}\text { "analyse de la valeur", "analyse } \\
\text { fonctionnelle", "AMDEC" }\end{array}$ & management \\
\hline Total productive maintenance & "méthode 5S", "TPM" & management \\
\hline Job rotation & "polyvalence" & scholars / management \\
\hline Multi-tasking & "polyvalence" & scholars / management \\
\hline Multi-skilling & "polyvalence" & scholars / management \\
\hline Autonomous work group & "equipes de travail autonomes" & management \\
\hline Problem solving groups & $\begin{array}{l}\text { "groupes de résolution de } \\
\text { problèmes" }\end{array}$ & management \\
\hline Project groups & "équipes de projet" & management \\
\hline Business process reengineering & "Reengineering" & management / journalists \\
\hline Downsizing & "restructuration" & journalists / euphem ism \\
\hline Core competencies & "recentrage sur le métier" & scholars / management \\
\hline Lean production & "production maigre" & scholars / journalists \\
\hline Multidivisional form & "organisation en centres de profit" & scholars / management \\
\hline $\begin{array}{c}\text { Formal in-house customer } \\
\text { suppliers contracts (?) }\end{array}$ & $\begin{array}{c}\text { "contrats clients / fournisseurs } \\
\text { internes" }\end{array}$ & management \\
\hline outsourcing & “externaliser" & scholars / management \\
\hline sub-contracting & "sous-traiter" & scholars / management \\
\hline
\end{tabular}

White areas correspond to practices that can be easily translated. For some of them, like "reengineering" or "TPM", the English term is directly used, for others, like "just-in-time" the translation is literal. Grey areas underline terms for which translation is not easy ${ }^{12}$.

12 This uneasiness may be a measure of our ignorance. Nevertheless, these translation problems are found in international comparison made by institutions like OECD or the European Foundation for the Improvement of Living and Working Conditions. Papers or questionnaires translated in French from the English are often difficult to understand (see for example OECD, 1999, EF, 1998). 


\section{Appendix 2 : French government surveys on technological and organizational change: ancestors the COI survey}

\section{1) Background}

The French government surveys organization topics since the middle of the 1980s'. Traditionally, the Ministry of labor has two domains of competence : work ("travail") and employment ("emploi"). The first has to do with industrial legislation, the second with labor market regulations. Surveys on organization originated from the "work" department. Interest in work organization came from the need to complement the information gathered through the national surveys on working conditions.

A first labor force survey was designed in 1987, under the acronym TOTTO ("enquête sur les Techniques et l'Organisation du Travail auprès des Travailleurs Occupés"), by a team under the direction of Michel Gollac. Its aim was to better understand how working conditions were related with work (task and technology) and worker (gender, age, social origin) characteristics. The TOTTO survey has been conducted again in 1993.

At the same time, the Ministry of labor launched a new business survey inspired by the British Workplace and Industrial Relations Survey (REPONSE survey), in order to improve knowledge about industrial relations in French firms. The conception of the REPONSE survey has been coordinated by Thomas Coutrot and Anna Malan.

At the end of the 1980's, the Ministry of industry designed, a system of annual surveys aiming at measuring the innovative behavior of firms. This took place in the context of the public debate on the productivity paradox. At the beginning of the $90 \mathrm{~s}$, most OECD countries had data bases on R\&D expenditures built according to the Frascati manual and they were implementing their innovation surveys along the lines of the OSLO manual. In 1991, Ministry of Industry conducted a first innovation survey. In 1993, a smaller survey on organizational change (the survey on "organizational change in production") was conducted to better understand the relations between technological innovation and organizational innovation. The design of this survey has been directed by Nathalie Greenan and Dominique Guellec.

\section{1) The "TOTTO" surveys (INSEE, 1987; DARES 1993)}

The "TOTTO" ("enquête sur les Techniques et l'Organisation du Travail auprès des Travailleurs Occupés") survey has been financed and conducted by the National Institute of Statistics and Economic Studies (INSEE) in 1987, financed by the Ministry of labor (DARES) and conducted by INSEE in 1993. Researchers from the fields of ergonomic, industrial medicine, psychology, sociology and economics contributed to the design of the questionnaire. Both in 1987 and in 1993, the survey was a supplement to the annual labor force survey and a sample of about 20000 occupied workers from all industries were interviewed.

Workers were asked about their perception of the way they work. The main topics of the questionnaire are the nature of tasks performed, timetables, hierarchical relation, autonomy, communication, work rhythm, deadlines and technology use. Information was gathered through face-to-face interviews of about 45 minutes, completed at the workers' home.

Workers also gave the name and address of their establishment, which allows to trace the firm identification number. This number is used in all the official surveys conducted at the firm level and in data files of government origin. Thus, matched employer/employee data sets can be generated from this type of surveys.

\section{2) The "REPONSE" survey (DARES, 1993)}

Financed by the Ministry of labor (DARES), this survey aims at measuring the social climate and the state of industrial relations. Researchers in economics and industrial relations, statisticians and firm representatives participated in the design of the questionnaire. Firm and trade union representatives of about 3000 establishments of firms over 50 employees from all industries were interviewed.

The employer was asked about social climate within the firms and about participatory devices ("pratiques participatives"): negotiation with trade union representatives, incentive strategy, conflicts, employee involvement schemes, technological and organizational innovations. Questions on technology and organization were asked to better understand the context of information sharing and to measure whether these topics were discussed directly or indirectly (through trade unions) with employees. A set of questions on the same topics (sometimes the same questions) were asked to trade union representatives, allowing to measure some the convergence or divergence in points of view. 


\section{3) The survey on organizational change in production (SESSI, 1993)}

Financed by the Ministry of industry (SESSI), the aim of this survey was to measure aspects of the firm's behavior that could influence its capacity to innovate and its competitivity. The group of experts that participated in the design of the questionnaire, was mainly composed of economists. 2600 manufacturing firms over 50 employees were interviewed.

The focus of the questionnaire is on the organization of the production department of the firm and on the use of advanced manufacturing technologies. The main topics are the objectives of organizational change, technology use, sharing of responsibilities for operating activities on the shopflor between operators, the supervisors and specialists, timetables, teamwork, change in competencies, quality norms, changes in formal relations between departments, impacts of organizational change on various indicators. As this survey was a postal survey, this questionnaire is a very short one (two pages), with mainly qualitative questions addressed to the production manager of the firm.

Whereas in the TOTTO survey, questions aim at measuring the main characteristics of jobs in terms of organization and technology use, in this firm level survey, most questions are on changes on a 5 years period. As a matter of fact, this is an output of the discussions about the design of both questionnaires. For the TOTTO survey, the group of experts felt that workers had to be asked some very simple questions about their everyday work, trying to formulate questions in the most "objective way". At the firm level, the interviewed person is expected to give an answer concerning the whole firm or part of it. Here, the "pilot" group felt that it was easier to respond about the change that occurred within the firm during a given period of time than about the state at a given date. In a way, it is assumed that their is much more heterogeneity within the firm in the state of organization than in organizational changes. 
Our synthetic variables aggregate questions from different areas of the questionnaire in order to build up measures on a chosen topics like communication, autonomy and work rhythm. We proceed by topic, the set of primary questions used is presented in box 2. We explain how the variables are built from the questions keeping in line with the notations in box 2 . In between brackets, we give the percentage of blue collar workers from manufacturing firms with more than 50 employees in each category, using weights to adjust for sampling rates and non response (sample of 2157 workers).

1) Intensity of vertical communication (CVER, 5 items)

With (c), a synthetic variable, taking its values between 0 and 1 indicates the size of the intervention sphere of the superiors:

ISPHERE $=$ (number of answers "yes" at questions $c_{1}$ to $\left.c_{6}\right) /(1+$ number of questions that apply)

The intensity of vertical communication is measured by the following variable:

CVER $=\left[\right.$ ISPHERE $\left.+\left(a_{1}=y e s\right)+\left(a_{2}=y e s\right)+\left(b_{1}=y e s\right)\right] /(1+$ number of questions that apply $)$

From which a variable with 5 items representing each about $20 \%$ of the sample, is constructed:

CVER0 $=($ CVER $\leq 0.125)$, CVER1 $=(0.125<$ CVER $\leq 0.25)$, CVER2 $=(0.25<$ CVER $\leq 0.4375)$,

CVER3 $=(0.4375<$ CVER $\leq 0.625)$, CVER4 $=($ CVER $>0.625)$

\section{2) Intensity of horizontal (CHOR, 4 items)}

The intensity of horizontal communication is measured by the following variable (varying from 0 to 1 ): $\mathrm{CHOR}=$ (number of answers "yes" to questions $\mathrm{a}_{3}, \mathrm{~b}_{2}, \mathrm{~d}_{1}$ and $\left.\mathrm{e}_{1}\right) /($ number of questions that apply)

From which a variable taking 4 items (representing respectively $26 \%, 29 \%, 34 \%$ and $12 \%$ of the sample) is constructed: $\mathbf{C H O R} 0=(\mathrm{CHOR} \leq 0.25), \mathbf{C H O R} 1=(0.25<\mathrm{CHOR} \leq 0.67), \mathbf{C H O R} 2=(\mathrm{CHOR}=0.751), \mathbf{C H O R} 3=(\mathrm{CHOR}=1)$

3) Intensity of communication with other departments (CWITH, 4 items)

The intensity of communication with other departments is measured by the following variable (varying from 0 to 1 ): $\mathrm{CWITH}=$ (number of answers "yes" to questions $\mathrm{a}_{4}, \mathrm{~b}_{3}, \mathrm{~d}_{2}$ and $\mathrm{e}_{2}$ )/(number of questions that apply)

From which a variable taking 4 items (representing respectively $47 \%, 27 \%, 17 \%$ and $10 \%$ of the sample) is constructed: $\mathbf{C W I T H} 0=(\mathrm{CWITH}=0), \mathbf{C W I T H} 1=(\mathrm{CWITH}=0.25), \mathbf{C W I T H 2}=(0.25<\mathrm{CWITH}<0,75)$, CWITH3 $=(C$ WITH $\geq 0.75)$

4) Intensity of communication with outside the firm (CBETW, 3 items)

The intensity of communication with outside the firm is measured by the following variable (varying from 0 to 1 ): CBETW $=$ (number of answers "yes" to questions $b_{4}, d_{3}$ and $\left.e_{3}\right) /($ number of questions that apply)

From which a variable taking 3 items (representing respectively $81 \%, 13 \%$ and $6 \%$ of the sample) is constructed: CBETW0 $=($ CBETW $=0)$, CBETW $1=(0<$ CBETW $\leq 0.5)$, CBETW $2=(0.5<$ CBETW $<1)$

5) Intensity of contact with the customer (CUS, 2 items)

A variable with 3 items (representing respectively $87 \%, 8 \%$ and $5 \%$ of the sample) is built from the answers to question I: CUS0 $=((\mathrm{m})=$ never $))$, CUS1 $=((\mathrm{m})=$ occasionally, $\mathbf{C U S 2}=((\mathrm{m})=$ regularly or all the time $)$

6) Number of meetings per year (MEET, 5 items)

A variable measuring the number of meetings per year with 5 items is constructed from this question (representing respectively $43 \%, 14 \%, 15 \%, 15 \%$ and $13 \%$ of the sample):

MEET $0=((f)=0), \operatorname{MEET} 1=((f)=1$ or 2$), \operatorname{MEET} 2=(1 \leq(f) \leq 9)$, MEET3 $=(10 \leq(f) \leq 16)$, MEET4 $=((f) \geq 17)$

7) Scope of initiative left by hierarchy (SCOPI, 5 items)

To compute the scope of initiative left by the hierarchy, we codify the answers with -1 if the worker has no scope of initiative, 0.5 if the scope of initiative is bounded and 1 if it is unbounded. A missing response or a response "does not apply" is coded with a 0 . The overall scope of initiative is thus given by: $\mathrm{SCOPI}=(\mathrm{a})+(\mathrm{g})+(\mathrm{h})+(\mathrm{i})+(\mathrm{j})$, which varies between -5 and 4 . From this variable, we build a variable with 5 items (representing respectively 19\%, 24\%, 22\%, 21\% and $14 \%$ of the sample): SCOPI0 $=($ SCOPI $\leq-3), \quad$ SCOPII $=(-3<$ SCOPI $\leq-1), \quad$ SCOPI $=(-1<$ SCOPI $\leq 0.5)$, SCOPI3 $=(0.5<$ SCOPI $\leq 2)$, SCOPI $4=($ SCOPI $>2)$

8) Propositions for process improvement (PPIM, 2 items)

A variable with two items (representing respectively $59 \%$ and $41 \%$ of the sample) has been constructed: PPIMY $=((\mathrm{k})=\mathrm{yes})$ and PPIMN=((k)=no).

9) Intensity of production work within a group (GROU, 4 items) 
A variable with 4 items (representing respectively $46 \%, 16 \%, 11 \%$ and $27 \%$ of the sample) is built from the answers to questions $I$ and $I_{1}$ : GROU0 $=\left((\mathrm{I})=\right.$ no), GROU1 $=\left((\mathrm{I})=\right.$ yes and $\left(\mathrm{I}_{1}\right)=$ less than $\left.1 / 4\right)$, GROU2 $=\left((\mathrm{I})=\right.$ yes and $\left(\mathrm{I}_{1}\right)=$ more than $1 / 4)$, GROU3 $=\left((I)=y e s\right.$ and $\left(I_{4}\right)=$ almost all the time $)$.

10) Work rhythm fixed by prescribed times (RXXX, 4 items)

A variable with 4 items has been computed to measure the tightness of quantitative norms and deadlines (representing respectively $25 \%, 22 \%, 23 \%$ and $31 \%$ of the sample):

$\mathbf{R N O P}=\left(\right.$ negative answers to $\mathrm{j}_{2}, \mathrm{j}_{3}$, and $\left.\mathrm{j}_{4}\right), \mathbf{R D A Y}=\left(\left(\mathrm{j}_{3}\right)=\right.$ yes and $\left(\mathrm{j}_{2}\right)=$ no and $\left(\mathrm{j}_{4}\right)=$ no), RHOU $=\left(\left(\mathrm{j}_{2}\right)=\right.$ yes and $\left(\mathrm{j}_{4}\right)=$ no $)$, RIMM $=\left(\left(\mathrm{j}_{4}\right)=\right.$ yes $)$.

11) Work rhythm fixed by horizontal linkages (RCXXX, 4 items)

A variable with 4 items (representing respectively $36 \%, 23 \%, 22 \%$ and $19 \%$ of the sample) measures if work rhythm is fixed by horizontal linkages:

$\mathbf{R C U C N}=\left(\right.$ negative answers to $\mathrm{j}_{4}, \mathrm{j}_{5}$ and $\left.\mathrm{j}_{6}\right), \mathbf{R C U S}=\left(\mathrm{j}_{4}\right)=$ yes or $\left(\mathrm{j}_{5}\right)=$ yes and $\left(\mathrm{j}_{6}\right)=$ no $), \mathbf{R C O L}=\left(\left(\mathrm{j}_{6}\right)=\right.$ yes and $\left(\mathrm{j}_{4}\right)=$ no and $\left(j_{s}\right)=$ no), $R C U C O=\left(\left(j_{4}\right)=\right.$ yes or $\left(j_{s}\right)=$ yes and $\left.j_{6}=y e s\right)$.

12) Work rhythm fixed by technical constraints (RTEC, 3 items)

A variable with 3 items (representing respectively $45 \%, 24 \%$ and $31 \%$ ) measures the intensity of technical constraints: RTEC $0=$ (negative answers to $j_{7}, j_{8}$ and $n_{1}$ ), RTEC1 $=$ (one positive answer), RTEC2 $=$ (more than one positive answers).

13) Precise quality norms prescribed (QUAL, 2 items)

A variable with two items (representing respectively $47 \%$ and $53 \%$ of the sample) has been constructed: QUALY $=((0)=y e s)$ and QUALN $=((0)=n o)$.

14) Participation in product testing (TEST, 2 items)

A variable with two items (representing respectively $48 \%$ and $52 \%$ of the sample) has been constructed: $\operatorname{TESTY}=((p)=y e s)$ and $\operatorname{TESTN}=((p)=n o)$. 